\title{
Isidoro de Sevilha nos legendários abreviados mendicantes hispanos do século XIII: uma abordagem historiográfica em perspectiva comparada
}

\author{
Isidore of Seville in the hispanic mendicants abbreviated legendaries in the 13th \\ century: a historiographical approach in a comparative perspective
}

\author{
Andréia Cristina Lopes Frazão da Silva* \\ Universidade Federal do Rio de Janeiro (UFRJ), Rio de Janeiro, RJ, Brasil
}

\begin{abstract}
RESUMO: Isidoro de Sevilha, falecido em 636, foi alvo de veneração durante todo o medievo. Contudo, com a trasladação das suas relíquias de Sevilha para Leão, ocorrida em 1063, diversas legendas, que sistematizaram e transmitiram novas informações sobre o Sevilhano, começaram a ser compostas. Desta forma, ocorreu a ampliação da memória hagiográfica sobre o bispo, finalizada na primeira metade do século XIII. Nos capítulos dedicados ao prelado nos legendários abreviados elaborados na Península Ibérica na segunda metade desse século pelo Dominicano Rodrigo de Cerrato e o Franciscano João Gil de Zamora, tais memórias são incorporadas. Por meio da comparação desses dois textos, em perspectiva historiográfica, foram identificados aspectos comuns e particulares, que foram analisados à luz do contexto de produção. A conclusão proposta é que os legendários imprimem sentidos distintos à figura de Isidoro. Enquanto o cerratense apresenta o bispo como um santo com perfil universal, o egidiano delineia um santo com uma vinculação particular com a monarquia castelhano-leonesa.
\end{abstract}

PALAVRAS-CHAVE: Isidoro de Sevilha. Legendários Abreviados. Mendicantes. Península Ibérica. Memória.

ABSTRACT: Isidore of Seville, who died in 636, was the target of veneration throughout the medieval period. However, with the relocation of his relics from Seville to Leon, which took place in 1063, several legends, which systematized and transmitted new information about the Sevillian, began to be composed. Thus, there was an expansion of the hagiographic memory about the bishop, completed in the first half of the 13th century. In the

\footnotetext{
"Professora Titular de História Medieval do Instituto de História da Universidade Federal do Rio de Janeiro (UFRJ). Bolsista Pq2 do CNPq e Cientista do Nosso Estado da FAPERJ. E-mail: andreiafrazao@terra.com.br https://orcid.org/0000-0003-0210-1166
} 
chapters dedicated to the prelate in the abbreviated legendaries elaborated in the Iberian Peninsula in the second half of this century by the Dominican Rodrigo of Cerrato and the Franciscan John Gil of Zamora, such memories are incorporated. By comparing these two texts, in historiographical perspective, common and particular aspects were identified and analyzed in the light of the production context. The proposed conclusion is that the legendaries give different meanings to the figure of Isidore. While the Cerratense presents the bishop as a saint with a universal profile, the egidian draws a saint with a particular link with the Castilian-Leonese monarchy.

KEYWORDS: Isidore of Seville. Abbreviated Legendaries. Mendicants. Iberian Peninsula. Memory.

\section{Introdução}

Durante todo o medievo, Isidoro de Sevilha, falecido em 636, foi alvo de veneração. Ainda que o primeiro texto de caráter hagiográfico dedicado ao bispo seja o Obitus b. Isidori Hispalensis ep., ${ }^{1}$ composto logo após a sua morte, ${ }^{2}$ as primeiras notícias conhecidas que apontam para um culto público ao confessor, segundo Baudouin de Gaiffier, datam de fins do século VIII. ${ }^{3}$ A partir desse momento, seu nome é incluído em sacramentários, calendários e breviários. ${ }^{4}$ Contudo, foi com a trasladação das relíquias de Isidoro de Sevilha para Leão, ocorrida em $1063,{ }^{5}$ que "la verdadera eclosión hagiográfica de Isidoro se va a producir", como sublinha Carriazo Rubio (2003, p. 8-9). Essa expansão dos escritos está diretamente relacionada à construção de novas memórias sobre o hispalense. Assim, foram elaborados textos que relatam eventos de caráter maravilhoso, até então não registrados, que teriam ocorrido durante a vida e após a morte de Isidoro, para atestar a sua santidade e o seu poder intercessor pelos fiéis.

A ampliação da memória hagiográfica sobre Isidoro finaliza na primeira metade do século XIII. É nessa conjuntura que foram incluídos capítulos sobre o bispo nos legendários abreviados mendicantes elaborados na Península Ibérica: a Vita s. Isidori (BHL 4487) das Vitae sanctorum nimia prolixitate descriptae de Rodrigo de Cerrato e a Vita s. Isidori das Legende Sanctorum et Festivitatum Aliarum De Quibus Ecclesia Sollempnizat (LS) de João Gil de Zamora. ${ }^{6}$ A proposta desse artigo é apresentar questões e interpretações iniciais a partir da comparação entre esses dois textos, em perspectiva historiográfica. Na comparação, considerei as fontes empregadas pelos autores, a estruturação e os conteúdos de cada capítulo. A partir do cruzamento desses dados, foram identificados e analisados aspectos comuns e particulares, à luz do contexto de produção de tais vitae.

\section{A eclosão hagiográfica sobre Isidoro de Sevilha}

José Carlos Martín-Iglesias, ${ }^{7}$ certamente o maior especialista contemporâneo nas hagiografias compostas sobre Isidoro de Sevilha, tema ao qual dedicou diversos trabalhos, publicou textos medievais em homenagem ao santo compostos desde o século VII, quando o bispo faleceu, até fins do medievo. ${ }^{8}$ Ele também realizou um inventário dessas obras. 9 Seguindo os estudos desse autor, passo a apresentar os materiais que, a partir do século XI, buscaram realçar a vida exemplar e os milagres operados pelo santo e contribuíram para ampliar as memórias de santidade relacionadas ao hispalense, justificando o uso da expressão “eclosión hagiográfica”.

A Vita s. Isidori de um Breviário da região de Leão ${ }^{10}$ é um texto anônimo escrito no século XI para uso litúrgico, provavelmente logo após o traslado das relíquias. Segundo Martín-Iglesias 
(2017, p. 8), este material "no es más que un centón elaborado a partir de la Renotatio de Braulio de Zaragoza, de un pequeño extracto de la noticia sobre Isidoro de Sevilla que Ildefonso de Toledo incluyó en su De uiris illustribus (CPL 1252) (cap. 8), y del Obitus de Redempto de Sevilla”. Ainda que não apresente aspectos novos, configura-se como uma síntese dos textos até então produzidos e é um testemunho do incremento do culto a Isidoro em área leonesa no período.

A Translatio s. Isidori Legionem (BHL 4488) ${ }^{11}$ é a primeira obra a relatar a descoberta das relíquias do bispo visigodo e sua trasladação. Foi redigido em Leão, talvez no último quarto do século XI. O autor, segundo Martín-Iglesias (2005, p. 199), era possivelmente um membro da Colegiada de S. Isidoro, ${ }^{12}$ onde as relíquias foram depositadas. Para Henriet (2004, p. 38), foi um monge de origem francesa, cluniacense, que vivia em Leão. Essa obra é um marco, pois com ela se inicia o registro textual de novas memórias relacionadas ao bispo.

Cerca de um século depois, entre 1185 a 1203, Martinho de Leão, cônego regular de S. Isidoro, compôs o Sermo in transitu s. Isidori (BHL 4485). ${ }^{13}$ Neste sermão, Isidoro figura como exemplo de sacerdote por suas muitas virtudes. Ele é caridoso, sábio, opositor à heresia, hospitaleiro, prudente, sóbrio, honesto etc. O religioso sublinha a importância de clamar ao bispo, que devido à sua vida agradável a Deus, tinha méritos para atuar como intercessor.

Entre fins do século XII e início do XIII, ou seja, na mesma conjuntura em que o sermão de Martinho foi elaborado, outro cônego de S. Isidoro de Leão, cujo nome não é conhecido, utilizando diversas fontes, escreveu três obras. ${ }^{14} \mathrm{~A}$ Vita s. Isidori (BHL 4486), ${ }^{15}$ que aborda a vida e a morte do prelado e, como salienta Henriet (2011, p. 708), apresenta Isidoro como "the successor of St James in the Iberian peninsula, portraying him as one of the main opponents of Arianism and highlighting his relationship with Pope Gregory the Great. It also presents Isidore as the first enemy of Islam in the peninsula, even before the invasion of 711". A segunda é a Adbreviatio Braulii Caesaraugustani episcopi de uita s. Isidori Hispaniarum doctoris (BHL 4486o), ${ }^{16}$ uma espécie de atualização da Renotatio librorum d. Isidori de Bráulio de Saragoça (BHL 4483) ${ }^{17}$ uma listagem dos textos escritos por Isidoro. Neste sentido, foram incluídos no rol de obras isidorianas aqueles materiais que, à época, acreditava-se que também haviam sido redigidos pelo bispo hispalense, tal como um comentário dos evangelhos e tratados de direito canônico e civil (MARTÍN-IGLESIAS, 2017, p. 203). A terceira é Historia translationis sancti Isidori (BHL 4491), ${ }^{18}$ que retoma o relato do traslado, acrescentando narrativas de milagres. ${ }^{19}$

No mesmo período, que provavelmente foi marcado por grande devoção a Isidoro de Sevilha em Leão e áreas próximas, como o noroeste peninsular, ${ }^{20}$ foi composto o sermão denominado Homilia in natale s. Isidori. ${ }^{21}$ Seu autor, Pedro Muñiz, ${ }^{22}$ foi deão e, posteriormente, bispo de Leão, chegando a arcebispo de Santiago de Compostela, cargo que ocupou até a sua morte, em 1224 (CAVERO DOMÍNGUEZ, 2015, p. 111-121). Segundo informações de Lucas de Tui, esta homilia foi elaborada como agradecimento pela cura, atribuída à intercessão de $S$. Isidoro, de uma enfermidade (MARTÍNEZ GONZÁLEZ, 1992, p. 111). O sermão realça as virtudes do sevilhano, comparando-o a personagens bíblicos e da história eclesiástica.

Miracula s. Isidori (BHL 5600) ${ }^{23}$ foi escrita por Lucas de Tui, que foi cônego de S. Isidoro de Leão e, a partir de 1239, bispo tudense. O texto foi elaborado quando Lucas ainda se encontrava na Colegiada leonesa, entre os anos 1221/4 e 1239/42. A obra menciona a trasladação das relíquias do prelado, sem descrevê-la em detalhes, mas narra milagres ocorridos nas décadas seguintes ao evento.

A Vita ss. Leandri, Isidori Hispalensis, Fulgentii Astigitani et Braulionis Caesarangustani ep. (BHL 4810) ${ }^{24}$ é um texto anônimo, redatado em Saragoça entre 1243 y 1271/2. Apesar de mencionar 
os quatro bispos que intitulam a hagiografia, o foco recai em Bráulio, que é o protagonista. Na legenda, Bráulio é apresentado como irmão de Leandro, Isidoro, Fulgêncio e Florentina, o que justifica a referência a tais personagens no título.

Por fim, fechando o ciclo hagiográfico isidoriano, destacam-se os capítulos que foram incluídos nos legendários abreviados mendicantes elaborados na Península Ibérica na segunda metade do século XIII, que, como assinalado, são o foco desta reflexão e serão apresentados a seguir.

\section{Os legendários abreviados de Rodrigo de Cerrato e de João Gil de Zamora}

A modalidade de texto denominada legendário surgiu no século VIII, mas, em fins do século XII, sofreu modificações, pois os redatores que antes copiavam as legendas em sua integridade passaram a resumi-las e reelaborá-las (DOLBEAU, 2010, p. 346). Tais materiais foram identificados como abbreviationes ou legendae novae (BAÑOS VALLEJO, 2003, p. 36).

Os religiosos mendicantes foram responsáveis pela produção de diversos legendários abreviados no século XIII. ${ }^{25}$ Como praticavam a pregação e a cura pastoral itinerantes, era necessário ter acesso a textos que sintetizassem informações e fossem de fácil transporte e consulta para a preparação de prédicas e a devoção particular. ${ }^{26}$ Neste sentido, reorganizaram relatos que já circulavam sobre santos e festas litúrgicas, além de produzirem coletâneas com conteúdos novos, narrando a trajetória dos irmãos que haviam se destacado por suas virtudes. Assim, foram compostos Abbreviatio in gestis et miraculis sanctorum, de Jean de Mailly (BHL 9034); $;{ }^{27}$ Liber epilogorum in gesta sanctorum, de Bartolomeu de Trento (BHL 9033); Legendae sanctorum, mais conhecido como Legenda Aurea, de Jacopo de Varazze (BHL 9035); Dialogus de Gestis Sanctorum Fratrum Minorum, cujo autor não é conhecido, ${ }^{28}$ e Vitas fratrum, de Gerard de Frachet (BHL 2223, 4451, 6723). ${ }^{29}$ Nesse conjunto, também se encontram as Vitae sanctorum nimia prolixitate descriptae, de Rodrigo de Cerrato, e as Legende Sanctorum et Festivitatum aliarum de quibus Ecclesia sollempnizat, de João Gil de Zamora. ${ }^{30}$

As VS foram organizadas no âmbito da Ordem dos Pregadores e transmitidas por sete manuscritos, datados como dos séculos XIII e XIV: vit. 28, da Biblioteca Capitular de Segóvia; ms. 146, da Biblioteca da Universidad Complutense; Lat 23333 y 2333A, da Bibliothèque Nationale de Paris; Add.30057 e 23935, do British Museum de Londres e ms. 82 da Bibliothèque Publique de Toulouse (PÉREZ-EMBID WAMBA, 2011, p. 105, nota 3). Por meio da comparação dos manuscritos, os especialistas ${ }^{31}$ concluíram que a VS foi elaborada em duas ediçóes. A primeira, finalizada por volta de 1260 , e a segunda, cerca de 1276 . Tais estudos salientam que a segunda edição, com maior número de capítulos, sofreu influências da Legenda Áurea, difundida a partir de 1264.

Em sua versão mais extensa, a que se encontra no manuscrito de Segóvia, o legendário contém um prólogo e 159 relatos sobre santos e festas, que estão organizados seguindo o calendário litúrgico, iniciando com De nativitate beate Virginis Marie e finalizando com De Johanne patriarca. A seguir há dois índices. ${ }^{32} \mathrm{O}$ primeiro apresenta, ao lado dos diversos tipos sociais, como arcebispos, mulheres casadas, peregrinos, enfermos, os capítulos mais adequados a tais grupos, e o segundo, seguindo a mesma lógica, indica temas, como avareza, jejum, esmola, humildade, ao lado dos capítulos relacionados. Por fim, é incluído o capítulo De Purificatione Sancte Marie. A obra está redigida em latim e em prosa. Vários capítulos das VS já foram publicados, mas a obra completa continua inédita. ${ }^{33}$ 
Como é indicado no texto, o responsável pela composição foi Rodrigo de Cerrato (Rodericus Cerratensis, em latim), sobre o qual há poucos testemunhos. A maioria das informações sobre sua biografia provém da própria VS (GARCÍA DE LA BORBOLLA). Ele nasceu na primeira metade do século XIII, na região de Cerrato, uma área de cerca de $1.534 \mathrm{~km}^{2}$, que abarca territórios das atuais províncias de Palência, Valladolid e Burgos. Não se sabe quando ingressou na ordem dominicana, nem onde estudou. Perez-Embid Wamba propõe que ele obteve a sua formação em Toulouse (2011, p. 105). Ele esteve vinculado ao convento de Santa Cruz de Segóvia, fundado em 1218, segundo os especialistas, a primeira comunidade dominicana organizada na Península Ibérica (LARRAÑAGA ZULUETA, 2019, p. 65-78). Angeles Borbolla afirma que ele atuou como professor em alguns conventos ibéricos, vindo a falecer em Zamora, em 1276 (online).

As LS foram elaboradas em latim e em prosa, em ambiente franciscano, provavelmente no Convento de Zamora, em fins do século XIII. ${ }^{34} \mathrm{Na}$ forma atual, reúne 88 capítulos, organizados por ordem alfabética, além do prólogo. A obra foi preservada de forma incompleta ${ }^{35}$ por um único manuscrito, o Add. 41070 (ff. 1-465v), que se encontra na British Library. ${ }^{36}$ Ele só contém o legendário. Segundo Martín-Iglesias, o códice é de origem hispânica e foi copiado no século XIV, ${ }^{37}$ mas não se sabe em qual local exato foi confeccionado (2015, p. 151). A edição crítica, latim-espanhol, foi preparada pelos professores José Carlos Martín-Iglesias e Eduardo Otero Pereira e publicada em 2014.

O responsável pelas LS foi o frade João Gil (Juan Gil de Zamora, em espanhol; Iohannes Egidii ou Egidius Zamorensis, em latim). ${ }^{38}$ Ele nasceu em Zamora, provavelmente no seio de uma família nobre. ${ }^{39} \mathrm{~A}$ data de seu nascimento ainda é motivo de controvérsias, mas há certo consenso de que ele ingressou na Ordem dos Frades Menores entre 1269-1271. Ele estudou no studium franciscano de Paris, possivelmente de 1273 até 1278, ou seja, por cerca de quatro anos, como estabelecido nas Constituições de Narbona (BIHL, 1941). Ele foi lector do convento de Zamora, ${ }^{40}$ custódio, e, como informam fontes tardias, vicário e, posteriormente, ministro da Província Franciscana de Santiago. Como ele dedicou obras a Afonso X e ao Infante Sancho, alguns autores propuseram a hipótese de que manteve relaçôes com a corte real castelhano-leonesa, o que estudos mais recentes têm questionado. Segundo um livro do século XVII, ele faleceu em 1318. ${ }^{41}$

Pelo caráter de compilação, para a elaboração dos capítulos das VS e das LS foram empregadas diversas e variadas fontes. ${ }^{42}$ Apesar de não terem produzido textos totalmente inéditos, defendo que Rodrigo e João Gil foram autores. Eles reuniram materiais, selecionaram dados, resumiram e/ ou reescreveram trechos de suas fontes, atentos aos objetivos de suas obras: disponibilizar materiais de fácil consulta para os seus irmãos. E fizeram-no em sintonia com as diretrizes de suas ordens e da Igreja Romana, influenciados pelos seus contextos específicos. O resultado foi a constituição de novas narrativas, que mesmo tributárias de materiais anteriores, apresentam singularidades.

Durante a pesquisa, só localizei um texto que se propóe a fazer comparações sistemáticas entre as ideias de Rodrigo de Cerrato e João Gil de Zamora. Trata-se do artigo Sobre el trasfondo social de la predicación mendicante en Castilla y León (siglo XIII), de autoria de Javier Pérez-Embid Wamba (2011, p. 105), cuja meta foi:

[...] buscar una aproximación al contenido y al contexto de esa predicación [mendicante], a través de la obra hagiográfica de un dominico castellano, Rodrigo de Cerrato, y de la de un franciscano leonés, Juan Gil de Zamora, así como, principalmente, de los sermones compuestos por éste último. 
Desta forma, a discussão realizada por esse autor é distinta da que desenvolvi e apresento de forma sintética - nesse texto, pois me detive na análise dos capítulos dedicados a Isidoro nas duas compilações.

\section{As VS e as LS e a construção de Isidoro como santo da Igreja universal}

Tanto a VS quanto a LS, como assinalado, contém capítulos dedicados a Isidoro de Sevilha. ${ }^{43}$ E, como já salientado, ainda que partindo de tradiçóes comuns, constituem textos distintos sobre o santo. Segundo Martín-Iglesias (2005, p. 225), a inclusão de tais capítulos em legendários ibéricos mendicantes "muestran cómo la figura de san Isidoro había pasado ya a formar parte del santoral de la Iglesia universal”. Concordo parcialmente com essa afirmação e passo a discuti-la.

No século XIII, as obras isidorianas eram reconhecidas como autoridade e, portanto, são citadas na Abbreviatio, Liber Epilogorum e na Legenda Aurea. Porém, tais legendários não contêm capítulos dedicados a narrar a trajetória e os milagres do bispo. Há de sublinhar que o Liber Epilogorum de Bartolomeu de Trento inclui uma notícia sobre o hispalense. ${ }^{44}$ Entretanto, ela não difere muito daquelas presentes nos calendários litúrgicos anteriores e ressalta, sobretudo, a sua autoridade como escritor: "XXXIII - De Sancto Ysidoro. Sanctus Ysidorus doctor eximius multos libros fecit, et inter ceteros librum Ethymologiarum. Sanctitate, fide et miraculis gloriosus, requievit in pace” (2001, p. 52).

Pode-se argumentar que o Liber epilogorum é marcado pela brevidade, mas quando esse capítulo é comparado aos outros da compilação, verifica-se o quanto o autor é ainda mais sintético ao mencionar Isidoro. Essa curta referência ao bispo pode ser explicada pelo fato de Bartolomeu não ter tido acesso aos textos que já circulavam na península ibérica no início da década de 1240 , momento de redação desse legendário, o que permite inferir que a constituição de Isidoro como santo da Igreja universal ainda estava em construção no decorrer do século XIII.

É possível, contudo, propor que as VS e as LS, devido à vinculação religiosa de seus autores a institutos mendicantes, tenham contribuído para a difusão de memórias de Isidoro no âmbito mais geral da Igreja Romana. Neste sentido, cerca de três séculos após a redação dos legendários ibéricos mendicantes, em fins do século XVI, foi realizada a inclusão do nome do bispo no Martirológio romano, com o seguinte registro: "Hispali in Hispania sancti Isidori episcopi, sanctitate et doctrina conspicui, qui zelo fidei et observantia ecclesiasticae disciplinae Hispanias illustravit” (GAIFFIER, 1961, p. 274).

A partir de tais considerações, um questionamento pode ser levantado: os capítulos sobre Isidoro nas VS e nas LS já o apresentam como um santo de caráter universal ou ainda vinculado às questões hispanas?

\section{A vida de Isidoro na VS e na LS em perspectiva comparada}

No artigo em que apresenta um completo inventário de obras compostas no medievo sobre Isidoro, ao abordar os capítulos sobre Isidoro nas VS e nas LS, Martín-Iglesias (2005, p. 225) afirma que o objetivo desses relatos era a "edificación moral y a la predicación”. Concordo com 
o autor, pois, incontestavelmente, a motivação central da redação das compilações, como salientado e explicitamente indicado no prólogo das obras, era disponibilizar materiais para o preparo de pregações e meditação dos frades.

Martín-Iglesias (2005, p. 225) acrescenta que tais narrativas estavam “ajenas a cualquier rivalidad política" e foram o ponto final do processo em que "se había impuesto la reputación de santidad sobre la de sabiduría”. Estas afirmativas suscitaram questionamentos que fundamentaram o meu exercício comparativo: as diferenças entre os capítulos são significativas? Relacionam-se ao âmbito social e ao contexto mais específico de produção de cada obra, incluindo as tensóes políticas? Quais açôes e virtudes são vinculadas à santidade de Isidoro em cada texto?

Como anunciado na introdução, na comparação privilegiei a estruturação formal dos textos, as fontes empregadas e os conteúdos de cada capítulo. Esse último aspecto, devido às diferentes escolhas dos autores e os questionamentos levantados, resultou na discussão sobre variados temas, que poderão, oportunamente, ser mais aprofundados em reflexões específicas.

O primeiro aspecto que salta aos olhos na comparação é a extensão dos capítulos. O redigido por Rodrigo de Cerrato é menor que o de Gil de Zamora. A brevidade do capítulo nas VS se relaciona ao estilo de escrita do dominicano, já realçado pelos estudiosos. Desta forma, Sanchez Alonso, na primeira metade do século passado, sublinhava que o legendário de Cerrato era formado por "biografías breves, poco dadas a lo maravilloso" (1947, p. 274), e Angeles Borbolla salienta que o autor "omite las escenas lentas y prolongadas, siendo incluso demasiado escueto en las narraciones de milagros".

Contrapondo as VS às LS, Pérez-Embid Wamba (2002, p. 308) sintetiza o grau de abreviação aplicado por Gil de Zamora às suas fontes face ao de Rodrigo de Cerrato:

En 465 folios, el texto [LS] incluye un total de 86 leyendas (mientras el códice de Segovia del Cerratense trae 158 en sus 230 folios): aun considerando la diferente organización codicológica - los vitas se copiaron en 4 columnas por folio - resulta evidente un índice de abreviación inferior en el legendario de Gil de Zamora.

No caso específico dos capítulos dedicados a Isidoro, além de diferentes estilos de abreviação, o tamanho se relaciona a uma seleção distinta de conteúdos por partes dos autores. Como é possível verificar na tabela comparativa anexa, Cerrato aborda eventos da vida e a morte de Isidoro, indicando somente a data do traslado de suas relíquias para Leão, enquanto Gil de Zamora narra esse episódio com vários detalhes, assim como relata milagres operados pelo hispalense junto ao seu sepulcro e suas apariçốes maravilhosas.

Essa seleção de conteúdos se vincula diretamente às fontes usadas pelos escritores. Segundo Martín-Iglesias (2008), João Gil utilizou as obras Vita s. Isidori (BHL 4486); Chronicon Mundi de Lucas de Tui; Translatio s. Isidori Legionem (BHL 4488); Historia translationis sancti Isidori (BHL 4491) e Historia de Rebus Hispanie de Rodrigo Ximenez de Rada.

Quanto às VS, após comparar o capítulo dedicado ao hispalense nessa obra ao das LS e com a Vita s. Isidori (BHL 4486), concluí que esse último texto foi a única fonte usada por Rodrigo de Cerrato, pois o autor não acrescenta nenhuma informação diferente daquelas presentes nessa obra. Além disso, suas intervenções no texto original são poucas: ele abrevia longos trechos compondo poucas frases ou incorpora algumas sentenças retiradas diretamente da Vita; em alguns casos, as frases são mantidas sem retoques ou sofrem mudanças pontuais, como a troca de termos por sinônimos ou reorganização da ordem das palavras. 
O uso unicamente da Vita s. Isidori por Rodrigo de Cerrato foi uma opção ou ele não teve acesso a outras fontes? Defendo que foi uma opção. O dominicano realizou diversas viagens para ensinar e recolher documentos para a escrita de seu legendário, como destacam os especialistas, e certamente poderia ter tido acesso aos textos produzidos em Leão e Toledo, todos redigidos no mínimo duas décadas antes da primeira edição das VS. Assim, seguindo o seu estilo, breve e sem dar destaque aos eventos milagrosos, proponho que a eleição da Vita como fonte exclusiva se relaciona ao principal objetivo do capítulo: enfatizar a trajetória virtuosa do arcebispo, não seus feitos post-mortem.

Em várias passagens das VS e das LS, os autores seguiram a mesma fonte, a Vita s. Isidori, mas realizaram uma seleção distinta de elementos. Por meio da análise comparativa dos conteúdos de cada capítulo, passo a apontar e discutir as semelhanças e diferenças que considero mais significativas.

Diferentemente do Cerratense, que inicia com a narração dos eventos, João Gil de Zamora, tal como faz em outros capítulos das LS, ${ }^{45}$ apresenta uma espécie de sumário do que será abordado:

Na hora de narrar a sagrada história do venerável doutor Isidoro, ocuparemo-nos, em primeiro lugar, de sua linhagem e sua vida enquanto permaneceu no século; em segundo lugar, da forma em que desempenhou seu cargo episcopal; em terceiro lugar de seus últimos dias; em quarto lugar, do traslado de seus restos, e em quinto lugar, dos milagres operados junto ao seu sepulcro. ${ }^{46}$

Essa introdução evidencia quais temas serão tratados no decorrer do capítulo, que, como assinalado, são em maior número do que os das VS. O recurso de indicar logo no início os tópicos que serão desenvolvidos está em harmonia com a estratégia didática utilizada na estruturação das LS. Essa obra apresenta os capítulos organizados em ordem alfabética para descomplexificar o manuseio pelos frades, opção que é explicada no prólogo: “[...] fiquem reunidas por escrito de um modo mais sistemático, estejam à disposição de todos com maior simplicidade, sejam encontradas com maior facilidade [...]”, ${ }^{47}$

No que concerne ao conteúdo propriamente dito, logo no início da narrativa, quando é apresentada a família de Isidoro, as obras apresentam diferenças. Cerrato segue unicamente a Vita s. Isidori e opta por não mencionar a mãe do arcebispo, presente em sua fonte: "em verdade, a mãe chamava Turtura". ${ }^{48}$ João Gil, seguindo dois diferentes trechos do Chronicon Mundi de Lucas de Tui, ${ }^{49}$ faz referência à mãe do bispo, indicando que seu nome era Teodora e que ela era filha do rei Sisebuto. Também menciona outra irmã além de Florentina: Teodósia, esposa de Leovigildo e mãe dos reis Hermenegildo - qualificado como mártir - e Recaredo. Desta forma, o relato das LS conclui que esses dois monarcas - figuras chaves na conversão dos visigodos ao cristianismo niceno - eram sobrinhos de Isidoro.

Como compreender tais diferenças? Rodrigo de Cerrato, seguindo o seu estilo sintético, pode ter considerado desnecessário incluir o nome da mãe de Isidoro, presente em sua fonte, por julgar que o dado não era imprescindível. No que se refere à omissão da outra irmã, uma possibilidade de interpretação estaria no fato do dominicano não ter tido acesso ao Chronicon Mundi e, portanto, nem ter tomado conhecimento desse dado, o que, como destaquei, parece-me improvável. Por fim, o autor pode ter concluído, baseando em seus conhecimentos prévios, que essas informações não eram confiáveis, escolhendo, portanto, não incorporá-las.

A inclusão de tais dados nas LS, por outro lado, também permite levantar algumas suposições. A primeira seria a preocupação em associar a figura de Isidoro à realeza, aspecto que é retomado em outros pontos do capítulo. A segunda pode se relacionar ao mesmo motivo apontado por 
Pérez-Embid Wamba (2015, p. 315) para explicar a inclusão de um capítulo dedicado a Isabel da Hungria ${ }^{50}$ nas LS: o patrocínio político.

Isabel foi uma princesa húngara que viveu entre 1207 a 1231. Ela foi casada com Ludwig IV, um landegrave da Turíngia, região que compunha o Sacro Império Romano Germânico. Ela foi canonizada em 1234 pelo papa Gregório IX e no decorrer do século XIII foi associada aos franciscanos. Ela era tia materna de D. Violante, que foi esposa de Afonso X e mãe de Sancho IV, ${ }^{51}$ dado que pode explicar a sua inclusão nas LS apesar de leiga, enquanto Clara de Assis e Antônio de Pádua, religiosos franciscanos canonizados, foram deixados de fora da compilação.

Além da relação de proximidade da família real com a santa, apontada por Wamba, há de sublinhar, como pesquisas já demonstraram, ${ }^{52}$ que rainhas e outras mulheres de destaque na corte castelhano-leonesas foram promotoras dos irmãos menores. Assim, João Gil, como franciscano, pode ter considerado importante dar visibilidade às mulheres na narrativa como uma deferência às apoiadoras dos menores.

Por fim, se considerarmos que as LS foram compostas quando Sancho IV já havia falecido, ${ }^{53}$ era a sua esposa, Maria de Molina, quem de fato governava. A regente enfrentou oposiçóes. Neste sentido, a menção às rainhas associadas a Isidoro - sua mãe e sua irmã - poderia ter como objetivo dar, ainda que de forma sutil, apoio político à rainha, que também era promotora dos franciscanos. ${ }^{54}$

A relação de Isidoro com a realeza castelhano-leonesa figura de forma efetiva nas LS, sobretudo nas partes 4 e 5 do capítulo (2014, p. 411-418). Desta forma, segundo a narrativa, o santo intervém a favor da monarquia, que também o prestigia, em diversas situações. É por meio de iniciativas de Fernando I que as relíquias do santo chegam a Leão e foi instituída a festa de celebração do traslado. Em uma aparição, o santo hispalense declara a Afonso VII que ele era, por designo divino, protetor de sua linhagem e seu apoiador na batalha vitoriosa contra os muçulmanos em Baeza. Esse monarca, por sua vez, em agradecimento, concedeu privilégios à Colegiada de S. Isidoro, e foi novamente recompensado, pois "todos os reis e príncipes das Hispânias submeteram-se ao seu comando" ${ }^{55}$ Por fim, informa que Isidoro, com Santiago, apoiaram o rei Fernando III em batalha contra os muçulmanos.

São narrados milagres nas LS nos quais os agraciados não são da família real, mas eles são em menor número se comparados àqueles cujos beneficiários foram os monarcas. Desta forma, nas LS, os reis são os principais protagonistas das dádivas divinas por meio da intercessão do santo, mas também na promoção do seu culto. Esse protagonismo pode ser interpretado como uma forma de reconhecimento nas LS da política favorável dos monarcas aos franciscanos, como apontado por diferentes pesquisadores. ${ }^{56}$

Nas VS a realeza também se faz presente, contudo, com menor ênfase. Na obra é informado que reis atuaram contra o cristianismo niceno, ${ }^{57}$ como Leovigildo, ou a favor, como Recaredo. Também há uma pequena passagem que indica que o rei Recaredo vinha até a cela onde vivia Isidoro para aprender com a sua sabedoria. Essa postura do monarca, registrada na obra, a meu ver, permite apontar para uma diferença de sentido dado às relações entre o prelado e a realeza face às das LS. Se naquele legendário há uma troca de favores entre o santo e a monarquia, nas VS, Isidoro parece ter um papel de guia espiritual do soberano, que, por sua vez, atua como um apoiador da ecclesia, ao combater a heresia.

Outra diferença a ressaltar é o tratamento dado a Leandro, irmão de Isidoro, seu predecessor no arcebispado. Mesmo que tomando por base comum a Vita s. Isidori, os autores salientaram elementos distintos em suas narrativas. Nas VS, Leandro é destacado por seu amor espiritual 
(diligebat puerum spiritualiter) pelo irmão mais novo, a quem ensinava; seu exílio, ocorrido devido às perseguições ao cristianismo niceno sob o governo de Leovigildo; seu papel no ingresso do irmão na vida reclusa e seu desejo de ver Isidoro quando pressentiu a sua morte. Ou seja, nas VS Leandro figura como uma espécie de tutor do caçula, atento à sua formação eclesiástica.

Nas LS, Leandro é apresentado como um defensor da fé na Trindade. Assim, o texto sublinha a sua amizade com o Papa Gregório, motivo que levou o último a desejar conhecer Isidoro; a sua participação em um sínodo em Constantinopla, ${ }^{58}$ para "reafirmar os artigos relacionados com a santa e imaculada Trindade"; 59 sua eficaz pregação, que motivou os godos a abandonarem o arianismo; suas instruçôes quanto aos preceitos e ofícios que deveriam ser seguidos pelos eclesiásticos; sua morte, após a restauração do credo niceno na igreja visigoda. Nessa obra, portanto, Leandro é caracterizado como um precursor, uma espécie de organizador da igreja na qual Isidoro ocuparia um papel de guia e intercessor.

O Papa Gregório também ganha nuanças distintas nas duas narrativas. Nos relatos, Isidoro conhece pessoalmente o papa em Roma, em uma viagem maravilhosa ocorrida na noite de Natal. Porém, se nas LS o desejo de conhecer Isidoro nasce da amizade com Leandro, como assinalado, nas VS, o motivo que move Gregório é a fama do hispalense como estudioso. Nas VS, o papa também confirma a eleição de Isidoro como arcebispo e lhe concede a dignidade de primado da Hispânia. Esses dados são omitidos nas LS, que informa sobre sua morte logo após noticiar a de Leandro, o que induz o leitor a concluir que tais eventos foram próximos. Esta obra, contudo, indica que, dentre as virtudes de Isidoro, ele detinha a dignidade de primado, o que significava, segundo o texto, exercer as funções do Papa nas Hispânias, e que ensinou a todos a obedecer ao bispo de Roma (2014, p. 410).

Essas diferenças na caracterização de Leandro e Gregório, na minha compreensão, estão associadas ao tratamento de outro aspecto das narrativas: a educação. Os dois capítulos mencionam a formação escolar de Isidoro e os frutos desse estudo, mas com variações. Os dois textos enfatizam que, ainda menino, Isidoro, por achar que não tinha capacidade e temendo as varadas do professor, foge de sua cidade e encontra uma mulher junto ao poço. Após observá-la e conversar com ela, concluiu que poderia ampliar seus conhecimentos, aprendendo um pouco a cada dia. Contudo, há detalhes distintos nos relatos. Passo a apresentá-los e discuti-los.

As VS, antes de narrarem esse evento, sublinham, como já destacado, que Leandro ensinava ao irmão; após, ressaltam o progresso intelectual de Isidoro, salientando que ele se entregou com humildade aos ensinamentos de seus professores, a ponto da graça celeste lhe ser infundida. Como resultado, tornou-se versado em latim, grego e hebraico; perfeito no Trivium e Quadrivium; ilustre nas doutrinas filosóficas e erudito nas leis humanas e divinas; insigne por sua vida e doutrina e suave no diálogo. Além disso, após relatar o encontro de Isidoro e Gregório em Roma, na noite de Natal, evento já referenciado, o autor, abreviando o que é discutido nos capítulos 6, 7 e 8 de sua fonte, registra que o hispalense "para a utilidade dos fiéis muitos livros compôs, extirpou muitas heresias". ${ }^{60}$

Ademais de sublinhar a formação e produção literária de Isidoro, as VS salientam a sua preocupação com a formação dos eclesiásticos. Assim, registra que ele era solícito como um pai e construiu um mosteiro onde os clérigos pudessem estudar por no mínimo quatro anos, salvo aqueles que se mostrassem mais dotados, que permaneceriam por mais tempo, para que não se afastassem do estudo. A obra indica o nome de dois desses alunos: Ildefonso e Bráulio.

Nas LS, sobre os estudos de Isidoro, após o relato do episódio da fuga, para realçar o seu progresso educacional, destaca que ele também foi abençoado com a graça divina, salientando que 
ela o tornou semelhante a Platão em talento, a Aristóteles em aplicação, a Túlio em eloquência, a Orígenes em erudição, a Agostinho em gravidade e a Gregório em doutrina. O tema da educação só é retomado ao final da parte 3, quando são apresentadas as virtudes do Hispalense em vida, logo após a informação do ano de sua morte. Desta forma, dentre suas muitas qualidades e feitos, indica-se que ele instruiu a igreja de Cristo com seus muitos livros.

Ainda que as VS e as LS abordem o tema, há, na minha interpretação, uma diferença quanto ao papel da educação nos dois capítulos. As VS, por meio dos dados que apresenta, sublinha a importância dos bispos na formação dos eclesiásticos, exemplificada, primeiro, pelas ações de Leandro, que instruiu e orientou o irmão, e, depois, as do próprio Isidoro, ao enfatizar os conteúdos que foram dominados pelo Santo, como línguas, doutrinas e leis e a iniciativa de construir um lugar para os clérigos estudarem; ao indicar que sua produção literária foi de utilidade para os fiéis e para o combate à heresia e ao explicar que foi a sua fama de bom estudante que motivou o papa Gregório a desejar conhecê-lo. Ou seja, o tema é abordado com caráter exemplar e didático. As LS, ainda que registrem o aproveitamento dos estudos de Isidoro, não detalham o que ele aprendeu, não ressaltam a sua atenção à instrução dos eclesiásticos e não relaciona seus escritos diretamente ao combate às heresias. As informações apresentadas somente salientam a figura excepcional de Isidoro, ao colocá-lo no mesmo patamar que Platão, Aristóteles, Túlio, Orígenes, Agostinho e Gregório.

Essa diferença de tratamento pode relacionar-se a dois aspectos principais. O primeiro, ao relevo que a Ordem dos Pregadores dava aos estudos, como já analisado por diversos autores, ${ }^{61}$ a fim de preparar os frades para a pregação e para ouvir confissões. O segundo, à responsabilidade dos líderes eclesiásticos de cuidar da formação de seus subordinados, como normatizado por Roma. ${ }^{62}$ Neste sentido, por meio do capítulo dedicado a Isidoro, Rodrigo de Cerrato insiste no valor da formação; na necessária dedicação aos estudos, que resulta na aprendizagem pela infusão da graça divina, e no dever de dividir com os outros, eclesiásticos e fiéis, o que foi aprendido.

Os frades menores, sobretudo a partir do Capítulo Geral de Narbona de 1261, também dão ênfase à educação dos irmãos. Mas no texto específico das LS sobre Isidoro, o tema não parece ser explorado como um aspecto modelar como nas VS. Em minha compreensão porque, como assinalado, o estudo nas LS é um recurso para alçar o Santo ao patamar de outras figuras notáveis.

Há um aspecto, presente na Vita s. Isidori, que só figura nas VS: a vida reclusa de Isidoro, desde a sua juventude até a sua eleição como arcebispo, e seu papel de promotor da vida religiosa feminina e masculina, inclusive patrocinando a construção de diversos mosteiros. Essa atenção aos religiosos segue, no texto, o relato de seu cuidado com a formação clerical. Assim, concluo que esses dados figuram para realçar o perfil do Prelado, atento aos diversos grupos sociais de sua diocese. Vale lembrar que Gil de Zamora conhecia essa vita, mas optou por não incluir essas notícias, provavelmente porque seu exercício de abreviação tinha outros objetivos.

Outro aspecto singular nas VS é a informação de que Isidoro não se limitava a atuar em uma única província, pregando por diferentes cidades e regióes. Esse dado, presente na fonte, provavelmente foi selecionado por Rodrigo de Cerrato por estar em harmonia com os princípios da espiritualidade mendicante: a pregação itinerante.

A pregação não está ausente das LS, mas nessa obra não há realce à itinerância, mas às exortações, apresentadas em discurso direto, como uma espécie de registro do que efetivamente havia sido proferido. Desta forma, após Isidoro interceder contra uma seca que assolava as Gálias e a Hispânia, chuvas abundantes foram enviadas, segundo o relato, em resposta à sua oração. O bispo então aproveita a oportunidade e fala às pessoas ao redor: "Está aqui irmãos, o que consegue a fé na 
santíssima trindade. Efetivamente, devido aos vossos rogos, foram concedidos a vós três benefícios: a saúde corporal, um tempo clemente, colheitas exuberantes e frutos abundantes”. ${ }^{63}$ Esse discurso, transcrito de sua fonte, é incluído na narrativa para reafirmar o credo niceno face aos grupos vistos como heréticos, e, pode-se supor, também contra as crenças muçulmanas.

O combate à heresia está presente nas duas obras, mas também com variações. Nas VS, ele é associado à produção literária de Isidoro; à sua preocupação com a disciplina clerical; à sua presença nos sínodos de Sevilha e Toledo e ao debate contra o herege Gregório. Nas LS, ainda que seja afirmado que o arcebispo foi perseguidor e martelo dos hereges, as ações narradas contra a heresia são protagonizadas, sobretudo, por seu irmão Leandro, que foi exilado, defendeu a Trindade no Sínodo de Constantinopla, pregou e converteu os hispanos ao credo niceno. Isidoro reafirma a Trindade no discurso citado e ganha de outro Gregório, identificado como um herege no relato, em um debate.

Também há diferenças no tratamento de Maomé. Nas LS, de forma muito breve, é informado que ele estava na Hispânia quando soube do retorno de Isidoro à Sevilha após uma viagem. E, aconselhado pelo diabo, que aparece ao profeta em forma de anjo, foge para o norte da África, onde atraiu a muitos. $\mathrm{O}$ argumento apontado pelo diabo foi que o arcebispo era inimigo de ambos. Ou seja, nessa narrativa, Isidoro não toma conhecimento da existência e, por extensão, da presença de Maomé na Ibéria.

Nas VS, esse relato é mais longo e interligado ao da besta que assolava os arredores de Sevilha, que é dominada pelo santo. ${ }^{64}$ Apresento, a seguir, a sequência da narrativa no legendário de Cerrato: Isidoro retorna para a sua cidade e toma conhecimento que Maomé está por perto, assim como um dragão desolador; ele pede que o profeta seja levado à sua presença, mesmo que à força; é apresentado o diálogo, que nessa versão é mais longo, entre Maomé e o diabo, que não aparece como anjo de luz. Na conversa, o diabo realça o poder de Isidoro e é questionado por Maomé: "se o prelado é tão poderoso, por que me disse que eu poderia ganhar toda a gente da Hispania para ti??”. O diabo então responde que soube por revelação divina que o arcebispo iria permanecer em Roma, mas que houve mudanças. ${ }^{65}$ Assim, aconselha Maomé a partir para a África bem rápido, onde teria sucesso. $\mathrm{O}$ texto ainda acrescenta que os enviados do arcebispo chegaram até Córdoba, conseguiram capturar alguns dos seguidores do profeta, e então voltaram para Sevilha. A partir desse ponto, é relatado o encontro de Isidoro com a besta e a ressuscitação de uma mulher grávida, que é muito semelhante nas duas versões.

Ou seja, as VS, face às LS, dão maior espaço para Maomé, que é associado de forma direta ao diabo, sendo caracterizado como o seu mensageiro. Também dá a Isidoro uma postura mais ativa na oposição ao profeta; se nas LS ele parece nem ter tomado conhecimento da presença de Maomé, nas VS, como assinalado, o bispo está ciente e manda trazê-lo, se preciso, com o uso de violência, à sua presença.

Por fim, quanto à informação sobre a morte de Isidoro, nas VS é anunciada e outros eventos preparatórios são citados: distribuição de dinheiro aos pobres, recolhimento na cela, confissão. Também é indicado o local de sepultamento do santo - entre os irmãos Leandro e Florentina -, o que não é ressaltado nas LS, certamente porque o foco está na Colegiada de S. Isidoro de Leão, para onde foram levados os seus restos mortais após a trasladação de 1063. Por fim, as VS sublinham que o arcebispo não deixou Testamento, pois tudo distribuiu entre os pobres. A inclusão dessa renúncia aos bens também pode ter sido motivada pela espiritualidade mendicante.

As LS, baseando-se em outra fonte, o Chronicon Mundi, após informar sobre a morte de Isidoro, passa a listar seus dons, virtudes e ações: profecia, generosidade, hospitalidade, serenidade, 
sinceridade, justiça, humildade, sobriedade, cuidado para com os clérigos e religiosos, obediência ao bispo de Roma, instrução da Igreja com seus escritos etc. Assim, por meio de suas qualidades e atos, legitima-se o seu culto e tudo o que é narrado a seguir. Como salientado, nas partes finais do capítulo das LS são relatados o resgate das relíquias pela própria intervenção do Santo e os milagres que realizou desde então.

Comparando a extensão das partes do capítulo nas LS, verifica-se que as 4 e 5 juntas são maiores que a união das 1,2 e 3 . Esse dado pode evidenciar que o objetivo do autor, mais do que apresentar a trajetória, era realçar os eventos maravilhosos relacionados às relíquias do santo que, por sua vez, se associam, sobretudo, aos reis, como já indicado.

As VS e as LS, ainda que sejam compilações, devido às fontes usadas e aos conteúdos selecionados e abreviados, acabam por compor relatos que, a despeito das semelhanças, encerram diferenças significativas e que, como novos textos, ganham sentidos distintos.

Para discutir tais sentidos, no caso específico das VS, há os índices que se encontram no Códice de Segóvia. Segundo tais listas, a vida de Isidoro era adequada a sermóes proferidos a arcebispos e a nobres e para abordar o tema oração (PÉREZ-EMBID WAMBA, 2011, p. 107, p. 111). Se, como afirma Pérez-Embid Wamba, Rodrigo de Cerrato é o autor dos índices, ${ }^{66}$ essas informações contribuem para a compreensão do objetivo que o dominicano atribuiu à sua vita de Isidoro.

Nas VS, o foco é a trajetória e a morte do arcebispo. Mesmo sem introduzir dados novos, ao selecionar, abreviar e reescrever passagens da Vita s. Isidori, o hispalense é apresentado como uma liderança imbuída de valores mendicantes: estuda, preocupa-se com a formação dos demais, pratica a pregação itinerante, distribui seus bens, luta contra a heresia, contrapõe-se à Maomé, reconhece e se submete à autoridade da Igreja de Roma. O relato é didático e modelar, pois o protagonista apresenta as qualidades de um líder ideal. Assim, não surpreende que seja recomendado o uso desse capítulo para sermóes dirigidos aos arcebispos e aos nobres. E como Isidoro clama pelos fiéis quando afetados pela seca e pela besta/dragão/serpente, também é um exemplo da eficácia da oração.

O capítulo das LS resulta da junção de um maior número de fontes. Nele, Isidoro é exaltado por suas muitas virtudes, sobretudo por seu poder intercessor. A pouca ênfase em eventos de luta contra a heresia e na contraposição a Maomé pode ser uma estratégia para indicar que mesmo tendo travado este combate no nível histórico, é, sobretudo, no meta histórico, espiritual, que o hispalense enfrenta os inimigos da fé cristã nicena. É o Isidoro santo que as LS destacam, reafirmando a sua excepcionalidade em cada evento maravilhoso narrado, mas com contornos locais e marcadamente políticos, pois os agraciados por seus milagres são, mormente, os reis de Castela e Leão.

\section{Considerações finais}

O culto a Isidoro de Sevilha, bispo que viveu entre os séculos VI e VII no reino visigodo, começou a se difundir no século VIII. A partir do século XI começam a ser escritos novos textos - vidas, sermóes, crônicas, relatos de traslado, tratado de milagres - que, pautados em obras anteriores, sistematizam novas memórias vinculadas ao prelado. Assim, na primeira metade do século XIII, um conjunto de memórias de santidade sobre o hispalense é consolidado. A partir delas, Rodrigo de Cerrato e João Gil produzem, na segunda metade desse século, capítulos sobre Isidoro para compor os seus legendários abreviados. 
Provenientes do ambiente mendicante, essas narrativas foram organizadas tendo como fim disponibilizar material de fácil consulta pelos frades para meditação e no preparo de pregações, que se dirigiam a diversos públicos. Assim, fundamentos da espiritualidade franciscana e dominicana - itinerância, pregação aos diferentes grupos de fiéis, assistência pastoral, pobreza - atravessaram, de forma mais ou menos explícita, a produção dos capítulos. Outros aspectos conjunturais e as vinculações dos autores também influenciaram tais composições.

Após a comparação entre os dois capítulos, é perceptível como o resultado final da aplicação da técnica de abbreviatio culminou na produção de textos distintos: um é mais longo que o outro; um se baseou em uma única fonte, o outro consultou diversas; um se centra unicamente na vida e morte de Isidoro, o outro enfatiza o traslado de suas relíquias e seus milagres post-mortem. Além dessas diferenças de caráter macro, na comparação do conteúdo são identificadas singularidades, ainda quando o mesmo evento é narrado, pois cada autor prioriza um conjunto de detalhes em detrimento de outros.

No caso específico das VS, é possível concluir que a escolha do que foi narrado e a forma adotada tinha por objetivo compor um texto voltado a pessoas de grupos sociais específicos e que exerciam liderança - arcebispos e nobres. Assim, Isidoro é caracterizado como oriundo de uma nobre estirpe; instruído; disciplinado; hábil no debate; apoiador de seus subordinados; atento aos inimigos. Mas também é evidenciado que, na escolha dos detalhes, foram selecionados aqueles em harmonia com os ideais mendicantes: valorização da educação; prática da pregação itinerante, defesa da fé cristã; não acúmulo de bens.

As LS apresentam um Isidoro que, a começar por suas origens familiares, vincula-se à realeza. Sua trajetória em vida, exemplar, o distingue e o habilita a ser o defensor dos cristãos ibéricos, apoiando as ações reais, mesmo após a morte. Há valores em harmonia com a espiritualidade mendicante permeando o texto - ele defende a ortodoxia e exorta os fiéis -, mas eles parecem estar em segundo plano. $\mathrm{O}$ foco está no maravilhoso, direcionado à luta contra os muçulmanos e ao fortalecimento da autoridade real.

Se considerarmos a hipótese de que as LS foram compostas no período de regência de Maria de Molina, entre 1295-1301, rainha que, segundo a historiografia, manteve relações próximas com os franciscanos, ${ }^{67}$ esse capítulo pode ter tido uma inspiração política para apoio explícito à rainha. Como já assinalado, esse período foi, segundo os estudiosos, particularmente conturbado. ${ }^{68}$ A presença de João Gil na corte real ainda é motivo de debates. Alguns autores defendem que ele teve um papel destacado nos governos de Afonso X e Sancho IV, mas teria perdido espaço com a ascensão de Molina. Mas são conjecturas. Contudo, para além de uma questão de proximidade pessoal, pode-se pensar nas LS também como um meio para expressar apoio institucional à monarquia e, em especial, à regente, já que, segundo apontam os biógrafos, por volta de 1295 , Gil se tornou vicário e, posteriormente, cerca de 1300, ministro da Província Franciscana de Santiago.

As VS e as LS, portanto, imprimem sentidos distintos à figura de Isidoro. As VS, ao alçar o santo como modelo de liderança a ser imitado, em harmonia com princípios mendicantes e sem vinculaçốes diretas a personagens "modernos", ${ }^{69}$ contribuem para transformar Isidoro em um santo com perfil universal. Nas LS, Isidoro mantém o caráter de santo particular, em um capítulo que apresenta teor político, legitimando e realçando a autoridade de uma monarquia singular, a castelhano-leonesa, face às demais realezas. ${ }^{70}$ 


\section{Referências}

ACTA SANCTORUM. Antwerp, v. 1, Aprilis, 1675.

AGUADÉ NIETO, Santiago. Alfonso X y las órdenes mendicantes. Saxonia Franciscana, Werl, v.10, p. 277-302,1998.

ARÉVALO, S. Isidori Hispalensis episcopi Hispaniarum doctoris opera omnia. Roma: Typis Antonii Fulgonii, 1797-1803. $7 \mathrm{v}$.

AYALA MARTÍNEZ, Carlos de. Fernando I y la Sacralización de la Reconquista. Anales de la Universidad de Alicante: Historia Medieval, Alicante, n. 17, p. 67-115, 2011.

BAÑOS VALLEJO, Fernando. Las Vidas de Santos en la literatura medieval española. Madrid: Laberinto, 2003.

BARBARÍN LÓPEZ, Aixa J. María de Molina, un referente en la diplomacia femenina bajomedieval (12641321). In: FERNÁNDEZ CADENAS, Nerea; MATEO PELLITERO, Pedro; MORÁN CORTE, Alberto (ed.). Mujeres, espacios e ideas: hacia una reconstrucción del Mundo Hispánico. León: Universidad de León, 2020. p. 69-83.

BARTOLOMEU DE TRENTO. Liber epilogorum in gesta sanctorum. Florença: Sismel-Edizioni del Galluzzo, 2001.

BEYERS, Rita. La réception médiévale du matériel apocryphe concernant la naissance et la jeunesse de Marie: le Speculum Historiale de Vincent de Beauvais et la Legenda aurea de Jacques de Voragine. In: COTHENET, Édouard et al. Marie dans les récits apocryphes chrétiens. v. 1. Paris: Médiaspaul, 2006. p. 179-200. 2 v.

BIHL, Michael (ed.). Constitutiones Generales Ordinis Fratrum Minorum Editae et Confirmatae. Archivum Franciscanum Historicum, Quarachi, n. 34, p. 13-94; p. 284-358, 1941.

BOTO VARELA, Gerardo. Morfogénesis espacial de las primeras arquitecturas de San Isidoro: vestigios de la memoria dinástica leonesa. In: HUERTA, Pedro Luis (coord.). Siete maravillas del románico español. Aguilar de Campoo: Fundación Santa María la Real; C.E.R., 2009. p. 151-191.

CARRIAZO RUBIO, Juan Luis. Isidoro de Sevilla, spiritu prophetiae clarus. En la España Medieval, Madrid, n. 26, p. 5-34, 2003.

CASTILLO MALDONADO, Pedro. In hora mortis: deceso, duelo, rapiña y legado en la muerte del obispo visigótico. Hispania Sacra, Madrid, v. 64, n. 129, p. 7-28, 2012.

CASTILLO MALDONADO, Pedro. La muerte de Isidoro de Sevilla: apuntes de crítica histórico-hagiográfica. Habis, Sevilha, n. 32, p. 577-596, 2001.

CASTRO Y CASTRO, Manuel de (ed.). Juan Gil de Zamora. De preconiis Hispanie. Madrid: Universidad de Madrid, Facultad de Filosofía y Letras, 1955.

CAVERO DOMÍNGUEZ, Gregoria. Pedro Muñiz, obispo de León (1205-1206) y arzobispo compostelano (12071224). In: CÓRDOBA DE LA LLAVE, Ricardo; PINO GARCÍA, José L. del; CABRERA SÁNCHEZ, Margarita (coord.). Estudios en homenaje al profesor Emilio Cabrera. Córdoba: Servicio de Publicaciones de la Universidad de Córdoba, 2015. p. 111-121.

CID GAVÍN, Alejandro. Doña Violante de Aragón, promotora y protectora de los mendicantes: el ejemplo de Allariz. In: GARCÍA-FERNÁNDEZ, Miguel; CERNADAS MARTÍNEZ, Silvia (coord.). Reinas e infantas en los reinos medievales ibéricos: contribuciones para su estudio. Actas del Congreso Internacional, Santiago de Compostela, 21-23 de mayo de 2014. Santiago de Compostela: Universidade de Santiago de Compostela, 2018. p. 143-152.

CRESTA, Gerald. Valor y sentido del conocimiento en las órdenes mendicantes del Siglo XIII. Acta Scientiarum. Education, Maringá, v. 32, n. 2, p. 141-151, 2010.

DELORME, Ferdinand (O. F. M.). Dialogus de gestis sanctorum fratrum minorum. Quaracchi: Ex typographia Collegii s. Bonaventurae, 1923.

DOLBEAU, François. Les prologues de légendairs latins. In: HAMESSE, Jacqueline (ed.). Les prologues médiévaux. Turnhout: Brepols, 2010. p. 345-393.

ESTÉVEZ SOLA, J. A. Historia translationis sancti Isidori (BHL 4491). In: CHARLO BREA, L.; ESTÉVEZ SOLA, J. A.; CARANDE HERRERO, R. Chronica Hispana saeculi XII. Turnhout: Brepols, 1997. p. 119-179.

FERRERO HERNÁNDEZ, Cándida. Liber contra uenena et animalia uenenosa de Juan Gil de Zamora. Barcelona: Reial Academia des Bones Lletres, 2009. p. 22-33. 
FLEITH, Barbara. Santa Agnes entre litterati e illitterati: Algumas observações através da história da utilização do legendário de Jacopo de Varazze. In: TEIXEIRA, Igor Salomão (org.). História e Historiografia sobre a Hagiografia Medieval. São Leopoldo: OIKOS, 2014. p. 72-99.

FLOREZ, Enrique. España Sagrada. Theatro Geographico-historico de la Iglesia de España. Madrid: Oficina de Antonio Marin, 1752. V. IX: La Provincia Antigua de la Bética, p. 358-365.

FOREVILLE, R. (ed.). Lateranense IV. Vitória: Eset, 1973.

FORTES, Carolina Coelho. O ratio studiorum da Ordem dos Pregadores no século XIII: considerações sobre a relação entre identidade e educação. Acta Scientiarum: Education, Maringá, v. 33, n. 1, p. 77-85, 2011.

GAIFFIER, Baudouim de. Le culte de saint Isidore de Séville. Esquisse d'un travail. In: DÍAZ Y DÍAZ, Manuel C. (ed.). Isidoriana. Estudios sobre San Isidoro de Sevilla en el centenario de su nacimiento XIV. Leon: Centro De Estudios San Isidoro, 1961. p. 271-283.

GARCÍA BALLESTER, Luís. Naturaleza y ciencia en la Castilla del siglo XIII los orígenes de una tradición: los Studia franciscano y dominico de Santiago de Compostela (1222-1230). Arbor: Ciencia, pensamiento y cultura, Madrid, n. 604-605, p. 69-126, 1996.

GARCÍA DE LA BORBOLLA, Ángeles. Rodrigo de Cerrato. Disponível em: http://dbe.rah.es/biografias/26816/ rodrigo-de-cerrato. Acesso em: 23 abr. 2020.

GARCÍA ORO, José. Francisco de Asís en la España medieval. Santiago de Compostela: Consejo Superior de Investigaciones Científicas; Liceo Franciscano, 1988.

GARCIA SANJUÁN, Alejandro. Declive y extinción de la minoria cristiana em la Sevilla Andalusí (ss. XI-XII). Historia. Instituciones. Documentos, Sevilha, n. 31, p. 269-286, 2004.

GERARDUS DE FRACHETO. Vitae Fratrum Ordinis Praedicatorum. In: GELABERT Fr., Miguel; MILAGRO Fr., José Maria (ed.). Santo Domingo de Guzman visto por sus contemporâneos. Madrid: BAC, 1967. p. 516-819.

GIMENEZ, José Carlos; ZLATIC, Carlos Eduardo. Entre os ataques nobiliárquicos e a coesão do reino: a atuação de María de Molina nas minoridades régias de Fernando IV e Alfonso XI. Diálogos, Maringá, v. 20, n. 2, p. 82-98, 2016.

GONZÁLEZ MÍNGUEZ, César. La figura de María de Molina como prudente pacificadora.e-Spania, n. 33, 2019. Disponível em: http://journals.openedition.org/e-spania/31335. Acesso em: 22 maio 2020.

GRAÑA CID, María del Mar. ¿Favoritas de la corona? Los amores del rey y la promoción de la Orden de Santa Clara en Castilla (SS. XIII-XIV). Anuario de Estudios Medievales, Barcelona, v. 44, n. 1, p. 179-213, 2014.

GRAÑA CID, María del Mar. Reinas, infantas y damas de corte en el origen de las monjas mendicantes castellanas (c. 1222-1316). Matronazgo espiritual y movimiento religioso femenino. In: GARÍ, Blanca (ed.). Redes femeninas de promoción espiritual en los Reinos Peninsulares (s. XIII-XVI). Roma: Viella; IRCVM, 2013. p. 21-43.

HEFELE, Karl Joseph. Histoire des conciles. Trad H. Leclerq. Paris: [s.n.], 1913. t. V, p. 1316-1398.

HENRIET, Patrick. La santidad en la historia de la Hispania medieval: una aproximación política-sociológica. Hagiografía y archivos de la Iglesia. Memoria Ecclesiæ, Oviedo, n. 24, p. 13-79, 2004.

HENRIET, Patrick. Rex, lex, plebs. Les miracles d'Isidore de Séville à León (Xle-XIIle siècles). In: HEINZELMANN, Martin; HERBERS, Klaus; BAUER, Dieter (ed.). Mirakel im Mittelalter. Konzeptionen, Erscheinungsformen, Deutungen. Stuttgart: Franz Steiner, 2002. p. 334-350.

HENRIET, Patrick. Vita Sancti Isidori. In: THOMAS, David; MALLETT, Alex (ed.). Christian Muslim relations: a bibliographical history (1050-1200). Leiden-Boston: Brill, 2011. p. 708-714.

IACOPO DA VARAZZE. Legenda Aurea. Edição dirigida por Giovanni Paolo Maggioni. Florença: Sismel-Edizioni del Galluzzo; Milano: Biblioteca Ambrosiana, 2007. 2 v.

JAVIER SIMONET, Francisco (ed.). Santoral Hispano-Mozarabe escrito en 961 por Rabi Bem Zais, obispo de lliberis. Madrid: Tipografia de Pascual Conesa, 1871.

JEAN DE MAILLY. Abbreviatio in gestis et miraculis sanctorum: supplementum hagiographicum. Editio princeps a cura di Giovanni Paolo Maggioni. Florença: SISMEL Edizioni del Galluzzo, 2013.

JUAN GIL DE ZAMORA. Legende sanctorum et festiuitatum aliarum de quibus ecclesia sollempnizat. Introdução, edição crítica e tradução anotada por Jose Carlos Martín, em colaboração com Eduardo Otero Pereira. Zamora: Instituto de Estudios Zamoranos, 2014. 
LARRAÑAGA ZULUETA, Miguel. El Convento Dominico de Santa Cruz la Real de Segovia durante las épocas medieval y moderna. In: SASTRE VARAS, Lázaro et al. VIII Centenario de la llegada de Santo Domingo a Segovia. Actas... Segóvia: Ayuntamiento de Segovia, 2019. p. 65-78.

LLAMAZARES, Fernando; ROBLES, Constantino (coord.). San Isidoro de León. Relicario de la monarquía leonesa. León: Edilesa, 2007.

LORENZANA (ed.). Sancti Martini Legionensis presbyteri et canonicii regularis Ordinis Sancti Augustini in regio coenobio Legionensis D. Isidoro Hispalensis sacro, Opera. v. 1, p. vii-xxiii. Segóvia: [s.n.], 1782-1786. 4 v.

LUCAS DE TUY. Milagros de San Isidoro. Traducción: Juan de Robles (1525). León: Universidad de León, 1992.

LUCAS TUDENSIS. Liber de miraculis S. Isidori. In: DELGADO, J. Jiménez. Latine scripta. Disquisitiones ad humaniorum litterarum cultum. Madrid: Matriti, 1978. p. 277- 283 (prólogo, capítulos 7, 42 e 52).

LUCAS TUDENSIS. Liber de miraculis S. Isidori. In: GONZÁLEZ, Antonio Viñayo. Santo Martino de León,1130?1203: vida, prólogos y epílogos parenéticos. León: Isidoriana, 2003.

LYNCH, C. H.; GALINDO, P. San Braulio obispo de Zaragoza (631-651). Su vida y sus obras. Madrid: Consejo Superior de Investigaciones Científicas, 1950.

MARTÍN PRIETO, Pablo. Sobre la promoción regia de la orden franciscana en la Corona de Castilla durante el primer reinado Trastámara. Hispania Sacra, Madrid, n. LIX, p. 51-83, 2007.

MARTÍNEZ GONZÁLEZ, Jímenez Manuel (ed.). Lucas de Tuy. Milagros de San Isidoro. Traducción Juan de Robles (1525). León: Universidad de León, 1992.

MARTÍN-IGLESIAS, José Carlos (ed.). Escritos Medievales en honor del obispo Isidoro de Sevilla. Turnhout: Brepols, 2017.

MARTÍN-IGLESIAS, José Carlos (ed.). Scripta de uita Isidori Hispalensis episcopi. Turnhout: Brepols, 2006.

MARTÍN-IGLESIAS, José Carlos (trad.). Vita ss. Leandri, Isidori Hispalensis, Fulgentii Astigitani et Braulionis Caesaraugustani ep. (BHL 4810). e-Spania, n. 4, dez. 2007.

MARTÍN-IGLESIAS, José Carlos. El corpus hagiográfico latino en torno a la figura de Isidoro de Sevilla en la Hispania tardoantigua y medieval (ss. XIII-VII). Veleia, Vitoria-Gasteiz, n. 22, p. 187-228, 2005.

MARTÍN-IGLESIAS, José Carlos. Relatos hagiográficos sobre algunos obispos de la España medieval en traducción: Ildefonso y Julián de Toledo (BHL 3917 y 4554), Isidoro de Sevilla (BHL 4488) y Froilán de León (BHL 3180), Veleia, Vitória-Gasteiz, n. 28, p. 209-242, 2011b.

MARTÍN-IGLESIAS, José Carlos. La Translatio S. Isidori Legionem Anno 1063 (BHL 4488). Introducción, estudio y edición crítica. Exemplaria classica: journal of classical philology, Huelva, n. 15, p. 225-253, 2011a.

MARTÍN-IGLESIAS, José Carlos. La Vita beati Hysidori de Juan Gil de Zamora. Cahiers de recherches médiévales, França, n. 16, 2008. Disponivel em: http://journals.openedition.org/crm/10742. Acesso em: 27 jun. 2018.

MARTÍN-IGLESIAS, José Carlos. Legende sanctorum et festiuitatum aliarum de Juan Gil de Zamora (o. Min.): metodologia de uma edición crítica. In: PENA GONZÁLEZ, Miguel Anxo; DELGADO JARA, Inmaculada (coord.). Métodos y técnicas en Ciencias Eclesiásticas: Fuentes, historiografía e investigación. Salamanca: Universidad Pontifícia de Salamanca, 2015. p. 139-164.

MORÁIS MORÁN, José Alberto. El ornato esculpido en el templo de Fernando I (San Juan Bautista/San Isidoro de León). De Arte, León, n. 13, p. 7-30, 2014.

MORETA VELAYOS, Salustiano. Notas sobre el franciscanismo y el dominicanismo de Sancho IV y María de Molina. In: IGLESIA DUARTE, José Ignacio de la; GARCÍA TURZA, Javier García; DE CORTÁZAR, José Ángel (coord.). Semana de Estudios Medievales, 6., Nájera, 1995. Actas... Logroño: IER, 1996. p. 171-184.

MULCHAHEY, M. Michele. “First the Bow Is Bent in Study ...”: Dominican Education Before 1350. Toronto: Pontifical Institute of Mediaeval Studies, 1998.

PAZOS, Manuel Rodríguez. Privilegios de Sancho IV a los franciscanos de la provincia de Santiago (1284) y de Castilla (1285). Archivo Ibero-Americano, Vitória, v. 36, n. 144, p. 529-552, 1976.

PEPIN, Paulette Lynn. María de Molina, Queen and Regent: Life and Rule in Castile-León,1259-1321. Lanham, MD: Lexington Books, 2016. 
PÉREZ-EMBID WAMBA, Francisco Javier. Hagiología y sociedad en la España Medieval. Castilla y León (Siglos XI-XIII). Huelva: Universidad de Huelva, 2002.

PÉREZ-EMBID WAMBA, Francisco Javier. Sobre el trasfondo social de la predicación mendicante en Castilla y León (siglo XIII). Erebea: Revista de Humanidades y Ciencias Sociales, Huelva, n. 1, p. 103-136, 2011.

RÍOS, Rita. The Role of the Mendicant Orders in the Political Life of Castile and León in the Later 13th Century. In: CIMDINA, Ausma (ed.). Religion and Political Change in Europe: Past and Present. Pisa: PLUS, Università di Pisa, 2003. p. 21-33.

ROCHWERT-ZUILI, Patricia. La actuación pacificadora de María de Molina. e-Spania. Revue interdisciplinaire d'études hispaniques médiévales et modernes, n. 20, 2015.

RODRÍGUEZ ARANGO, María de los Angeles. María de Molina, reina y personaje dramático. Publicaciones de la Institución Tello Téllez de Meneses, Palência, n. 36, p. 59-87, 1975.

ROJO ALIQUE, Francisco Javier. Intelectuales franciscanos y monarquía en la Castilla medieval. Sémata: Ciencias Sociais e Humanidades, Santiago de Compostela, n. 26, p. 297-318, 2014.

RUSSEL, Bertrand. Lúcifer: o diabo na Idade Média. São Paulo: Madras, 2003.

SÁNCHEZ ALONSO, Benito. Historia de la historiografía española. Madrid: C.S.I.C., 1947. p. 274.

SILVA, Andreia Cristina Lopes Frazão da. Education, Dominican Order and Hagiography: a comparative analysis of Legenda Beati Petri Gundisalvi and Legenda Sancti Dominici. Acta Scientiarum. Education, Maringá, v. 37, p. 335-347, 2015.

SILVA, Andreia Cristina Lopes Frazão da. Franciscanismo e Hagiografia no século XIII: primeiras reflexões sobre o Legendário Abreviado de João Gil de Zamora. In: SIMPÓSIO NACIONAL DE HISTÓRIA: HISTÓRIA E O FUTURO DA EDUCAÇÃO NO BRASIL, 30., 2019, Recife. Anais Eletrônicos... Recife, 2019. Disponível em https://www.snh2019.anpuh.org/resources/anais/8/1564286367_ARQUIVO_TextoAndreiaCristinaLopesFrazaoDaSilvaAnpuh 2019.pdf. Acesso em: 18 maio 2020.

SILVA, Andreia Cristina Lopes Frazão da. João Gil de Samora. In: SOUZA, Guilherme Queiroz de; NASCIMENTO, Renata Cristina de Sousa (org.). Dicionário: cem fragmentos biográficos. A idade média em trajetórias. Goiânia: Tempestiva, 2020. p. 451-456.

VIÑAYO GONZÁLEZ, Antonio. Cuestiones histórico-críticas en torno a la traslación del cuerpo de san Isidoro. In: DÍAZ Y DÍAZ, Manuel C. (ed.). Isidoriana. Estudios sobre san Isidoro de Sevilla en el XI. V Centenario de su nacimiento. León: Centro De Estudios San Isidoro, 1961. p. 285-297.

VIVES CASTELL, Jose. Las “Vitas Sanctorum” del Cerratense. Analecta sacra tarraconensia: Revista de ciències histórico eclesiàstiques, n. 21, p. 157-176, 1948.

\section{Anexo}

\begin{tabular}{|l|l|}
\hline VS & LS \\
\hline Família de Isidoro. & $\begin{array}{l}\text { Introdução, apresentando os temas abordados no } \\
\text { capítulo. }\end{array}$ \\
\hline $\begin{array}{l}\text { Isidoro, ainda bebê, é coberto por abelhas, mas não fica } \\
\text { ferido. }\end{array}$ & $\begin{array}{l}\text { Família de Isidoro. } \\
\text { ferido, ainda bebê, é coberto por abelhas, mas não fica }\end{array}$ \\
\hline $\begin{array}{l}\text { Isidoro, por acreditar que não tinha capacidade para os } \\
\text { estudos, foge e após conversar com uma mulher perto de } \\
\text { um poço, retorna à sua cidade e se torna um aluno aplicado. }\end{array}$ & $\begin{array}{l}\text { Isidoro, por acreditar que não tinha capacidade suficiente para } \\
\text { um poço, retorna à sua cidade e se torna um aluno aplicado. }\end{array}$ \\
\hline O progresso intelectual de Isidoro. & O progresso intelectual de Isidoro. \\
\hline $\begin{array}{l}\text { Na noite de Natal, de forma maravilhosa, Isidoro vai até } \\
\text { Roma e encontra Gregório. }\end{array}$ & $\begin{array}{l}\text { Na noite de Natal, de forma maravilhosa, Isidoro vai até } \\
\text { Roma e encontra Gregório. }\end{array}$ \\
\hline
\end{tabular}




\begin{tabular}{|c|c|}
\hline VS & $\mathbf{L S}$ \\
\hline \multicolumn{2}{|l|}{$\begin{array}{l}\text { As perseguiçóes sofridas e a firmeza de Isidoro face aos } \\
\text { ataques dos arianos. }\end{array}$} \\
\hline $\begin{array}{l}\text { O fim das perseguições arianas e a restauração da paz da } \\
\text { igreja hispânica com a ascensão ao trono de Recaredo. }\end{array}$ & $\begin{array}{l}\text { O fim das perseguiçóes arianas e a restauração da paz da } \\
\text { igreja hispânica com a ascensão ao trono de Recaredo. }\end{array}$ \\
\hline \multicolumn{2}{|l|}{ Leandro retorna do exílio. } \\
\hline & $\begin{array}{l}\text { Leandro participa de um sínodo em Constantinopla e defende } \\
\text { a teologia da Trindade. Nessa ocasião conhece Gregório. }\end{array}$ \\
\hline & $\begin{array}{l}\text { Leandro ao retornar à Hispânia, prega aos godos, que se } \\
\text { convertem. Após o batismo, conquistam a Galiza. }\end{array}$ \\
\hline \multicolumn{2}{|l|}{$\begin{array}{l}\text { Leandro, vendo a constância de Isidoro, tendo um pressá- } \\
\text { gio de que ele poderia ir para terras estrangeiras e objeti- } \\
\text { vando que seu corpo e mente não fossem maculados, leva } \\
\text { o irmão para viver recluso em uma cela. }\end{array}$} \\
\hline \multicolumn{2}{|l|}{$\begin{array}{l}\text { O Rei Recaredo visitava Isidoro em sua cela e aprendia } \\
\text { com ele sobre a fé. }\end{array}$} \\
\hline \multicolumn{2}{|l|}{$\begin{array}{l}\text { Leandro, pressentindo a morte, deseja ver Isidoro, que, } \\
\text { porém, declara que continuaria em sua cela enquanto } \\
\text { seu irmão vivesse. }\end{array}$} \\
\hline \multirow[t]{2}{*}{ Morte de Leandro. } & Morte de Leandro. \\
\hline & Morte de Gregório. \\
\hline \multicolumn{2}{|l|}{$\begin{array}{l}\text { Eleição de Isidoro, por unanimidade, pelo rei, príncipes, } \\
\text { bispos e povo. }\end{array}$} \\
\hline \multicolumn{2}{|l|}{$\begin{array}{l}\text { O Papa Gregório confirma a eleição e concede a Isidoro a } \\
\text { dignidade de Primado da Hispânia. }\end{array}$} \\
\hline \multicolumn{2}{|l|}{ As virtudes de Isidoro como arcebispo. } \\
\hline \multicolumn{2}{|l|}{$\begin{array}{l}\text { Isidoro constrói mosteiros para homens e mulheres } \\
\text { viverem reclusos e um mosteiro onde os jovens, como } \\
\text { Ildefonso e Bráulio, poderiam educar-se. O arcebispo } \\
\text { também zela pela disciplina de clérigos e monges. }\end{array}$} \\
\hline \multicolumn{2}{|l|}{$\begin{array}{l}\text { Isidoro percorreu cidades e regióes pregando, } \\
\text { chegando a Roma. }\end{array}$} \\
\hline \multirow[t]{2}{*}{$\begin{array}{l}\text { Ao retornar, Isidoro encontrou uma grande seca nas } \\
\text { Gálias e Hispânia. Após a intercessão de Isidoro, a seca } \\
\text { terminou, a saúde da terra e das pessoas foi restaurada. }\end{array}$} & $\begin{array}{l}\text { Ao retornar, Isidoro encontrou uma grande seca nas } \\
\text { Gálias e Hispânia. Após a intercessão de Isidoro, a seca } \\
\text { terminou, a saúde da terra e das pessoas foi restaurada. }\end{array}$ \\
\hline & $\begin{array}{l}\text { Isidoro fala ao povo, reafirmando a importância da fé na } \\
\text { Trindade. }\end{array}$ \\
\hline \multicolumn{2}{|l|}{$\begin{array}{l}\text { Ao retornar a Hispalis, Isidoro é informado que ali se } \\
\text { encontrava Maomé e que um dragão desolava áreas da } \\
\text { cidade. }\end{array}$} \\
\hline \multicolumn{2}{|l|}{$\begin{array}{l}\text { Isidoro mandou buscar Maomé para trazê-lo à sua pre- } \\
\text { sença, mesmo que à força. }\end{array}$} \\
\hline $\begin{array}{l}\text { O diabo aparece a Maomé e diz que Isidoro era adversário } \\
\text { de ambos e o convence a ir para o norte da África. }\end{array}$ & $\begin{array}{l}\text { O diabo aparece a Maomé em forma de anjo, diz que Isidoro } \\
\text { era adversário de ambos e o convence a ir para o norte da África. }\end{array}$ \\
\hline $\begin{array}{l}\text { O autor situa a pregação de Maomé no tempo de Sise- } \\
\text { buto e Heráclio. }\end{array}$ & \\
\hline
\end{tabular}




\begin{tabular}{|c|c|}
\hline VS & $\mathbf{L S}$ \\
\hline $\begin{array}{l}\text { Isidoro, no local denominado Santa Eulalia, encontra o } \\
\text { dragão e o expulsa. }\end{array}$ & $\begin{array}{l}\text { Isidoro, no local denominado Santa Eulalia, encontra o } \\
\text { dragão e o expulsa. }\end{array}$ \\
\hline $\begin{array}{l}\text { Ao retornar a Hispalis, Isidoro é recebido por uma mul- } \\
\text { tidão. Uma mulher grávida morre sufocada no tumulto, } \\
\text { mas é ressuscitada por intercessão do santo. }\end{array}$ & $\begin{array}{l}\text { Ao retornar a Hispalis, Isidoro é recebido por uma mul- } \\
\text { tidão. Uma mulher grávida morre sufocada no tumulto, } \\
\text { mas é ressuscitada por intercessão do santo. }\end{array}$ \\
\hline \multicolumn{2}{|l|}{ Celebração do sínodo em Hispalis. } \\
\hline Debate com o ariano Gregório. & Debate com o ariano Gregório. \\
\hline Cura de um cego. & Cura de um cego. \\
\hline \multicolumn{2}{|l|}{ Isidoro anuncia a sua morte e convoca o Sínodo de Toledo. } \\
\hline \multicolumn{2}{|l|}{ Isidoro vai ao sínodo de Toledo. } \\
\hline \multicolumn{2}{|l|}{$\begin{array}{l}\text { Ao retornar, Isidoro adoece e prepara-se para a chegada } \\
\text { da morte. }\end{array}$} \\
\hline \multirow[t]{3}{*}{ Morte de Isidoro. } & Morte de Isidoro. \\
\hline & As virtudes e ações de Isidoro como arcebispo. \\
\hline & Informação sobre a data de morte de Isidoro. \\
\hline $\begin{array}{l}\text { Após falecer, do corpo de Isidoro exalou agradável } \\
\text { perfume e muitos foram curados por sentir esse odor ou } \\
\text { tocar em seu corpo. }\end{array}$ & $\begin{array}{l}\text { Após falecer, do corpo de Isidoro exalou agradável } \\
\text { perfume e muitos foram curados por sentir esse odor ou } \\
\text { tocar em seu corpo. }\end{array}$ \\
\hline $\begin{array}{l}\text { Alguns têm uma visão na qual a alma de Isidoro ascen- } \\
\text { dia aos céus. }\end{array}$ & $\begin{array}{l}\text { Alguns têm uma visão na qual a alma de Isidoro ascen- } \\
\text { dia aos céus. }\end{array}$ \\
\hline Informação sobre a data de morte de Isidoro. & Informação sobre a data de morte de Isidoro. \\
\hline \multicolumn{2}{|l|}{$\begin{array}{l}\text { Informação sobre o testamento e o local de sepulta- } \\
\text { mento de Isidoro. }\end{array}$} \\
\hline \multirow[t]{5}{*}{$\begin{array}{l}\text { Indicação do ano em que os sarracenos conquistaram a } \\
\text { Hispânia e a reação de Pelágio. }\end{array}$} & $\begin{array}{l}\text { Indicação do ano em que os sarracenos conquistaram a } \\
\text { Hispânia e a reação de Pelágio. }\end{array}$ \\
\hline & $\begin{array}{l}\text { Apresentação do rei Fernando I e relato da trasladação } \\
\text { das relíquias de Isidoro de Sevilha para León. }\end{array}$ \\
\hline & $\begin{array}{l}\text { Depósito das relíquias de Isidoro na Igreja de S. João } \\
\text { Batista e instituição da festa de celebração da trasladação. }\end{array}$ \\
\hline & $\begin{array}{l}\text { Face à alegria do traslado, o rei Fernando, sua esposa e } \\
\text { filhos serviram, como serventes, alimentos aos presentes. }\end{array}$ \\
\hline & $\begin{array}{l}\text { Informação de que o local de depósito das relíquias de Isi- } \\
\text { doro tornou-se espaço de devoção onde ocorreram milagres. }\end{array}$ \\
\hline \multirow[t]{3}{*}{$\begin{array}{l}\text { Indicação da data de trasladação do corpo de Isidoro } \\
\text { para León. }\end{array}$} & $\begin{array}{l}\text { Indicação da data de trasladação do corpo de Isidoro } \\
\text { para León. }\end{array}$ \\
\hline & $\begin{array}{l}\text { Milagre do frio excepcional ocorrido em Hispalis no ano } \\
\text { do traslado das relíquias de Isidoro. }\end{array}$ \\
\hline & $\begin{array}{l}\text { Devido às dúvidas sobre o local de depósito das relíquias } \\
\text { de Isidoro e do sepultamento de Alvito, por sugestão do } \\
\text { abade de Silos, os corpos foram colocados em distintos } \\
\text { carros, puxados por cavalos, e sem a direção humana } \\
\text { chegaram a igrejas distintas. As relíquias de Isidoro } \\
\text { foram colocadas em S. João Batista e Alvito foi sepultado } \\
\text { na Igreja da Mãe de Cristo. }\end{array}$ \\
\hline
\end{tabular}




\begin{tabular}{|l|l|}
\hline VS & LS \\
\hline & $\begin{array}{l}\text { Durante o reinado de Afonso VI, um judeu se converte } \\
\text { após presenciar um milagre na Igreja de Isidoro. }\end{array}$ \\
\hline & Cura de um menino surdo e mudo proveniente de Astorga. \\
\hline & $\begin{array}{l}\text { Um soldado condenado pelo rei à pena capital refugiou- } \\
\text {-se na Igreja de Isidoro. O rei proibiu dar-lhe alimentos } \\
\text { ou bebida. Após 7 dias brotou da pedra aos pés do } \\
\text { celebrante da missa uma água que alimentou o soldado. } \\
\text { Essa água também curou enfermos. }\end{array}$ \\
\hline & Morte do rei Fernando I. \\
\hline & $\begin{array}{l}\text { O autor indica as fontes utilizadas: crônicas de Rodrigo e } \\
\text { de Lucas de Tui. }\end{array}$ \\
\hline & $\begin{array}{l}\text { Milagre das águas que brotavam das pedras do altar, } \\
\text { que curaram a muitos, mas também sinalizaram dificul- } \\
\text { dades futuras. }\end{array}$ \\
\hline Aparição de Isidoro para Afonso VII em Baeza. \\
\hline & $\begin{array}{l}\text { Benesses promovidas pelo rei Afonso VII para a } \\
\text { comunidade de cônegos de S. Isidoro e as graças divinas } \\
\text { recebidas pelo rei. }\end{array}$ \\
\hline & $\begin{array}{l}\text { Isidoro faz uma aparição e manda avisar ao Rei Fer- } \\
\text { nando III de um ataque dos sarracenos. Santiago e } \\
\text { Isidoro ajudam a Fernando III nessa batalha. }\end{array}$ \\
\hline & $\begin{array}{l}\text { Informação de que S. Isidoro e Santiago são defensores } \\
\text { da Hispânia e aparecem frequentemente em batalhas } \\
\text { apoiando aos cristãos para glória de Jesus Cristo. }\end{array}$ \\
\hline & \\
\hline
\end{tabular}

\section{Notas}

${ }^{1}$ Publicado em latim (MARTÍN-IGLESIAS, 2006, p. 379-388) e em espanhol (MARTÍN-IGLESIAS, 2017, p. 87-91).

2 Obra escrita por Redempto, clérigo de Sevilha, logo após o falecimento do prelado, ou seja, ainda em 636 . 0 texto narra os últimos dias e as virtudes demonstradas por Isidoro nesse período (CASTILLO MALDONADO, 2001; 2012).

${ }^{3}$ Gaiffier (1961, p. 274) afirma que a primeira invocação a Isidoro se encontra no Saltério de Carlos Magno, datado entre 795 a 800. Esse Saltério foi transmitido pelo Ms. Lat. 13159 da Biblioteca Nacional de Paris. Disponível em: https://archivesetmanuscrits.bnf.fr/ark:/12148/cc 91798. Acesso em: 23 mar. 2020.

${ }^{4}$ Como exemplos, podemos sublinhar o Calendário de Córdoba, datado de 961, que já indica a festa de Isidoro no dia 4 de abril: "Et festum sane ti Isidori archiepiscopi yspalensis" (JAVIER SIMONET, 1871, p. 21). Gaiffier também menciona os Calendários de Usuardo e de Senlis, as Litanias de Freising, Münstereifel, Tegernsee e Lobbes. Idem.

${ }_{5}^{5}$ Sobre essa trasladação, há diversas interpretações, como as de Viñayo González (1961); Garcia Sanjuán (2004); Henriet (2002); Martín Iglesias (2005); Ayala Martínez (2011).

${ }^{6}$ Optei por manter o nome do autor traduzido do latim para o português, assim como a grafia do nome das cidades.

${ }^{7}$ Registro meu agradecimento ao professor José Carlos Martin Iglesias, que disponibilizou, em meio à obrigatoriedade de isolamento social devido ao Covid-19, tanto na Espanha quanto no Brasil, cópia do texto Escritos Medievales en honor del obispo Isidoro de Sevilla, imprescindível para as reflexões aqui apresentadas.

${ }^{8}$ Essas edições estão listadas na bibliografia final.

${ }^{9} \mathrm{O}$ autor, em artigo publicado em 2005, esclarece: “deben de existir aún con toda probabilidad otros escritos dedicados a la memoria del obispo hispalense, al menos, en códices de carácter litúrgico como breviarios y leccionarios, el presente catálogo habrá de ir siendo puesto al día por otros estudiosos conforme avance el conocimiento de los textos latinos que nos han legado nuestros antepasados medievales" (p. 189). 
${ }^{10}$ Publicado em latim (MARTÍN-IGLESIAS, 2006, p. 405-412) e traduzido para o espanhol (MARTÍN-IGLESIAS, 2017, p. 93-97).

${ }^{11}$ Publicada por Martin-Iglesias em latim (2011a) e em espanhol (2011b, em artigo, e 2017, p. 99-106, em livro).

${ }^{12} \mathrm{O}$ espaço identificado como a Igreja de São João Batista e São Pelágio, após o traslado das relíquias, foi dedicado a Isidoro. Sobre este templo, ver Llamazares, Robles (2007); Boto Varela (2009); Moráis Morán (2014).

${ }^{13}$ Publicada em latim (ARÉVALO, 1797, p. 57-63) e traduzido para o espanhol (MARTIN-IGLESIAS, 2017, p. 107-114).

${ }^{14}$ Essas três obras foram reunidas entre 1257-1270 e incluídas na Vitae confessorum, compilação preparada a pedido de Afonso X por Bernardo de Brihuega, cônego da Sé de Sevilha.

${ }^{15}$ Esse texto foi publicado em latim, com lacunas, na Acta sanctorum, Aprilis (1675, p. 330-351). 0 trecho que falta nessa edição foi publicado por Martín-Iglesias (2005, p. 227-28), que também o traduziu para o espanhol (MARTíN IGLESIAS, 2017, p. 115-200).

${ }^{16}$ Esse texto foi publicado em latim na Acta sanctorum, Aprilis (1675, p. 351-352), e traduzido para o espanhol por Martin-Iglesias (2017, p. 200-206).

${ }^{17}$ Essa obra foi publicada por Martin-Iglesias em latim (2006, p. 199-207) e em espanhol (2017, p. 83-86).

${ }^{18}$ Editado em latim-espanhol (ESTÉVEZ SOLA, 1997, p. 119-179).

${ }^{19}$ Há que destacar que outras obras também apresentam o relato da trasladação das relíquias de Isidoro, como a História Silense, escrita entre 1110-1130, em Leão, provavelmente por um monge proveniente de Silos; a Crônica Najerense, composta entre 1160-1200, possivelmente em Santa Maria de Nájera; o Chronicon mundi, de autoria de Lucas de Tui, redigido por volta de 1238 em Leão; De rebus Hispaniae, de autoria do arcebispo toledano Rodrigo Jimenez de Rada, finalizada, em 1243; Primeira Crônica Geral de España, composta a mando do rei Afonso X, entre 1270-1284.

${ }^{20}$ Destaco, por exemplo, os dados que apontam para a presença de culto a Isidoro na Diocese de Braga nos séculos XII-XIII. Por um lado, as leituras referentes a S. Isidoro transmitidas pelos Breviários de Braga (Ms. e.IV.10, f. cccxxv ra-va -El Escorial, Biblioteca do Real Monastério de S. Lourenço, século XV) e de Soeiro (Ms. 657, f 209vb - f. 210 rh , Braga, Arquivo Distrital, Século XIV-XV), que devem remontar ao século XII (MARTíN-IGLESIAS, 2005). Por outro, notícias de templos dedicados a Isidoro no vale do Vouga, ainda no século XI; no Porto, em 1102, e Ribatâmega, área atualmente denominada Canaveses, em 1115. Cf. https://www.rotadoromanico.com/pt/monumentos/igreja-de-santo-isidoro-de-canaveses/. Acesso em: 23 mar. 2020; https://www.rotadoromanico.com/media/documents/Igreja_Isidoro.pdf e https://pesquisa. adporto. arquivos.pt/details?id=478117. Acesso em: 10 abr. 2020.

${ }^{21}$ Obra publicada em latim (2006, p. 109-122) e em espanhol (2017, p. 207-223) por Martin-lglesias.

${ }^{22}$ Patrick Henriet identificou a autoria e a divulgou na conferência Un texto hagiográfico desconocido sobre San Isidoro escrito por Pedro Muñiz a finales del siglo XI, no curso Poder y Hagiografía: Santos y reliquias en la España medieval, promovido pela Universidad de León e realizado na Colegiada de S. Isidoro em 10 de julho de 2012. Cf. https://journals. openedition.org/e-spania/20965?file=1.

${ }^{23}$ Só fragmentos dessa obra foram editados (LORENZANA, 1782, p. vii-xxiii; LUCAS TUDENSIS, 2003; 1978, p. 277- 283). Há uma tradução em espanhol, preparada por Juan de Robles no século XVI e publicada por Martínez González em 1992.

${ }^{24}$ Edição de fragmentos em latim (LYNCH, GALINDO, 1950, p. 325-330, 341-347, 357-361) e em espanhol (MARTíNIGLESIAS, 2007; e 2017, p. 225-297).

${ }^{25}$ Nos séculos seguintes, houve a produção de novos legendários abreviados, como os de Pedro Calo (BHL 9039), Bernardo Gui (BHL 9037) e Guido de Castris (BHL 9038)

${ }^{26}$ Posteriormente, essas compilações, em especial a Legenda aurea, passaram a ter outros usos. Sobre o tema ver Fleith (2014).

${ }^{27}$ Segundo Beyers, essa obra teve três edições. A primeira, datada de 1225-1230, quando o autor era clérigo em Auxerre. Alguns anos após ingressar na ordem dos pregadores, preparou uma segunda edição. Por fim, em 1243, fez uma revisão, realizando adições e adaptações “concernant surtout sa nouvelle famille religieuse" (2006, p. 184).

${ }^{28}$ Obra que narra a trajetória e milagres de diversos frades menores, em forma de diálogo.

${ }^{29}$ Essa obra reúne relatos sobre irmãos pregadores que se destacaram por suas virtudes.

${ }^{30}$ Essas obras serão indicadas a partir desse ponto do texto com a siglas VS e LS.

${ }^{31}$ Segundo Perez-Embid Wamba (2002, p. 216), são conclusões de Dondaine e Diaz y Diaz. Infelizmente não tivemos acesso aos artigos citados por esse autor.

32 Os índices foram publicados por Perez-Embid Wamba (2011, p. 107; 109-112). 
${ }^{33}$ Como Enrique Florez (Cf. España Sagrada, v. III, p. 398-400; V, p. 521-525, VII, p. 241-243; IX, p. 342-343 e 358-363 e X, p. 494-496. Volumes disponíveis em: https://pt.wikipedia.org/wiki/Espa\%C3\%B1a_Sagrada. Acesso em: 22 maio 2020), Jose Vives Castell (1948) e Perez-Embid Wamba (2002). Há uma edição do Ms. de Segóvia preparada por Francisco Villamil Fernández, como trabalho de conclusão de doutorado, mas ainda não publicada.

${ }^{34}$ Os editores apontam como terminus post quem das LS o momento posterior à redação da Historia naturalis, que teria sido composta entre 1279 e 1289 (MARTIN IGLESIAS E OTERO PEREIRA, 2014, p. 322-33).

${ }^{35}$ Faltam a vida de Lázaro, o capítulo sobre o Natal e todas as narrações referentes à letra Z.

${ }^{36}$ A British Library disponibiliza cópias digitais de diversos manuscritos em seu site (Cf. https://www.bl.uk/manuscripts/), entretanto, uma cópia do ADD. 41070 ainda não se encontra online. Informações sobre o manuscrito podem ser encontradas em: http://searcharchives.bl.uk/IAMS_VU2:IAMS032-002092977.

${ }^{37}$ Dolbeau data esse manuscrito como de fins do século XIII (2010, p. 372, nota 98).

${ }^{38}$ Além das LS, João Gil escreveu outras obras sobre temas diversos. Ainda não há uma listagem definitiva de seus escritos.

39 Baseados em uma notícia de Jacobo de Castro, publicada na página 160 do primeiro volume de El árbol cronológico de la provincia de Santiago, de 1727, os autores apontam para a família dos Gil Manríquez de Villalobos. A obra de Castro está disponível em: https://play.google.com/store/books/ details?id=YvpXbLxMrlcC\&rdid=bookYvpXbLxMrlcC\&rdot=1.

${ }^{40}$ Ainda que Rodrigo tenha falecido em Zamora, não é possível concluir que João o conheceu nessa cidade, sobretudo porque, segundo os especialistas, entre 1273 a 1278 ele se encontrava estudando no Reino da França, como sublinhado.

${ }^{41}$ Para mais detalhes sobre a trajetória de João Gil, ver Castro y Castro (1955, cap. 1) e Ferrero Hernández (2009, p. 22-33). Também publiquei um verbete sobre a biografia de Juan Gil (SILVA, 2020, p. 451-456).

${ }^{42}$ No tocante às LS, também foram utilizados materiais procedentes de uma obra composta por Gil anteriormente, o Liber illustrium personarum (MARTIN-IGLESIAS, 2015, p. 219).

${ }^{43}$ Em minha pesquisa utilizei as edições da Vita S. Isidoro das VS publicadas em Florez (1752, p. 358-365) e Arevalo (1797, p. 86-92). Segundo Martin-Iglesias, a Vita s. Isidori mudou de lugar na edição de 1276 das VS, antes capítulo LXXXIV, depois XCIX, mas não sofreu reelaboração (2005, p.192-193). Para o estudo das LS, consultei a edição de Martin-Iglesias e Otero Pereira, já citada.

${ }^{44}$ Registro aqui meu agradecimento a Igor Salomão Teixeira, que disponibilizou uma cópia do capítulo sobre Isidoro do Liber epilogorum in gesta sanctorum, além do acesso ao legendário de Mailly.

${ }^{45}$ Os capítulos das LS se iniciam de formas diversas: alguns com questões etimológicas, outros com pequenos resumos do conteúdo ou com dados sobre as fontes.

${ }^{46}$ Tradução livre a partir da edição de Martin Iglesias e Otero Pereira. Texto em latim: “Hysidori doctoris uenerabilis sacram ystoriam describentes, primo agemus de ipsius genere ac conuersacione in statu seculari, secundo in statu pontificali, tercio de ipsius consummacione finali, quarto de translacione, quinto de miraculorum operacione" (2014, p. 406).

${ }^{47}$ Tradução livre a partir da edição de Jose Carlos Martín e Eduardo Otero Pereira. Texto latino: “artificialius scribantur, subtilius habeantur, facilius inueniantur, forcius imprimantur" (2014, p.132). A dinâmica de leitura dessa obra no momento de sua produção se relacionava às atividades de pregação e cuidado pastoral exercida pelos frades menores. Desta forma, podemos supor que a leitura era realizada em função dos temas e públicos a quem se dirigiam as prédicas ou exortações. Assim, eram recolhidos trechos de diferentes capítulos, que eram combinados entre si e com outras fontes, como textos bíblicos e patrísticos. Ou seja, os capítulos não eram, necessariamente, lidos do início ao fim (SILVA, 2019).

${ }^{48}$ Tradução livre a partir da Acta Sanctorum. Texto latino: “mater vero Turtura vocitata” (1675, p. 330, col. 1).

${ }^{49}$ Conforme a edição de Martin-Iglesias, Chronicon Mudi, praef. 21. 37-48 e 2, 68, 1. 2-4 (2008, online).

50 Isabel é a forma em português do nome latino Elisabeth.

${ }^{51}$ Pérez-Embid Wamba ainda sublinha que Isabel da Hungria, devido ao casamento de sua irmã, também chamada Violante, com o rei Jaime I, vinculava-se à casa real de Aragão, e, desta forma, "aportava um flujo de santidade a ambas dinastias" (2015, p. 315)

52 Ver, por exemplo, García Oro (1988); Martín Prieto (2007); Graña Cid (2013 e 2014); Cid Gavín (2018).

${ }^{53}$ Sancho IV faleceu em 1295 e seu filho, Fernando, foi coroado. Mas como tinha cerca de 9 anos, sua mãe, Maria de Molina, atuou como regente.

${ }^{54}$ Sobre Maria de Molina ver, dentre outros Rodríguez Arango (1975); Moreta Velayos (1996); Rochwert-Zuili (2015); Pepin (2016); Gimenez, Zlatic (2016); González Mínguez (2019); Barbarín López (2020). 
${ }^{55}$ Tradução livre a partir da edição de Jose Carlos Martín e Eduardo Otero Pereira. Texto latino: "omnes Hyspaniarum reges et principes suo imperio subderentur" (2014, p. 417).

${ }^{56}$ Sobre o tema, ver, dentre outros, Pazos (1976); Garcia Oro (1988); Moreta Velayos (1996); Aguadé Nieto (1998); Ríos (2003); Martín Prieto (2007); Rojo Alique (2014).

${ }^{57}$ Ou seja, aqueles grupos cristãos que seguiam o credo aprovado no Concílio de Nicéia, realizado em 325, que reafirmava a ideia da Trindade.

${ }^{58}$ O texto das LS explica que foi nessa ocasião que Gregório e Leandro se conheceram $(2014$, p. 408).

59 Tradução livre a partir da edição de Jose Carlos Martín e Eduardo Otero Pereira. Texto latino: “pro confirmandis sancte et immaculate Trinitatis capitulis" (2014, p. 408).

${ }^{60}$ Tradução livre a partir da edição de Florez. Texto latino: "Ad vtilitatem fidelium multos libros composuit multas haereses extirpauit" (1752, p. 359).

${ }^{61}$ Sobre o tema, ver García Ballester (1996); Mulchahey (1998); Cresta (2010); Fortes (2011); Silva (2015).

${ }^{62}$ Por exemplo, o Concílio de Latrão IV deliberou que em cada catedral deveria ter um professor para ensinar os clérigos e outros alunos pobres (Cânone 11) e sublinha que os bispos deveriam estar atentos à formação do clero de suas dioceses, só ordenando os realmente capacitados para as atividades pastorais (Cânone 27). Os cânones podem ser consultados em Hefele - Leclerq (1913) e Foreville (1973).

63 Tradução livre a partir da edição de Jose Carlos Martín e Eduardo Otero Pereira. Texto latino: “Ecce, fratres, quantum obtinet fides sanctissime Trinitatis. Tria enim uobis a Domino per peticionem uestram beneficia sunt collata, scilicet sanitas corporis, temperies aeris et exuberacio frugum ac fructuum habundancia" (2014, p. 409).

${ }^{64} \mathrm{Nas}$ LS, Isidoro também combate um dragão/besta/serpente. O dragão, na tradição cristã, foi associado à serpente desde o século I d.C. e, por extensão, ao diabo. As obras não apresentam diferenças significativas ao narrar esse evento (RUSSEL, 2003, p. 64).

${ }^{65} \mathrm{O}$ diabo faz uma reflexão sobre porque as coisas aparentemente certas de acontecer mudam: pode ser por vontade de Deus, ou pela maldade humana, ou até pelo arrependimento, citando, inclusive, versos bíblicos.

${ }^{66} \mathrm{O}$ editor das listas, Perez-Embid Wamba, após apresentá-las, afirma: “En este listado de exempla (cuyo orden alfabético se pierde al traducirlo del latín) se ignoran por completo los santos hispanos, dirigiéndose la atención del hagiógrafo hacia todas las categorías hagiológicas, apóstoles, mártires o confesores, en mayor medida los antiguos que los "modernos". Entretanto, Isidoro figura entre os capítulos listados no índice (2011, p. 112).

${ }^{67}$ Sobre o tema ver, dentre outros, Pazos (1976); Moreta Velayos (1996); González Mínguez (2019).

${ }^{68}$ Sobre o tema ver, dentre outros, Rodríguez Arango (1975); Gimenez e Zlatic (2016); Rochwert-Zuili (2015) e Pepin (2016).

${ }^{69}$ Moderno, aqui, é usado no sentido de personagens que viveram quando os reinos castelhano e leonês já estavam estabelecidos - unidos sob uma única coroa ou separados -, como Fernando I, Fernando II, Afonso VII, dentre outros.

${ }^{70}$ Agradeço a Elias Nunes Frazão e Leila Rodrigues da Silva pela leitura e sugestões feitas ao texto do artigo.

Data de recebimento: 19/08/2020

Data de aprovação: 20/01/2021 